العدد الثامن عشر(Y V • Y) الجزء الخامس

A Socio-morphological Study of Selected Egyptian Place Names with Special Reference to

Booij's Construction Morphology

Presented by

Sondos Mohamed Abdel-Haleem Mohamed

Teaching Assistant

at

The Department of English Language and Literature

Faculty of Women for Arts, Science and Education 


\title{
A Socio-morphological Study of Selected Egyptian Place Names with Special Reference to Booij's Construction Morphology
}

\begin{abstract}
Most of the Egyptian place names are derived from various languages that were spoken in Egypt centuries ago. These languages include Ancient Egyptian, Coptic, Greek, etc. The contact between Arabic, after the Islamic Advent, and these languages was essential in shaping the forms of the Egyptian place names. However, other places acquired their names after the Arab conquest of Egypt, which are similarly of interest to the present research. This paper investigates the sociomorphological alterations that some of the Egyptian place names have undergone to reach their currently used forms. For this purpose, the researcher uses the tools of the theory of Construction Morphology (CM), developed by Booij (2005), under the fabric of socio-morphology. CM tackles any linguistic unit as a "pairing of form and meaning" or a function related to that form. Hence, $\mathrm{CM}$ is considered one of the adequate means to conduct this analysis; because it deals with the various linguistic levels, i.e. phonology, syntax, morphology, and even pragmatics, on an equal basis. To meet the goals of the study, the selected forms are analyzed in order to detect any significant modifications that they have undergone. The results demonstrate that a large number of these names was subject to various morpho-phonological alterations in order to reach the currently used forms for different reasons. These include socially governed purposes, ease of articulation, and the influence of Coptic, which ceased to generate new forms or schemas. In addition, since schemas in CM are language specific, new ones had to be developed to account for the Arabic place names under analysis.
\end{abstract}

Keywords: Egyptian place names, Contact Linguistics, Sociomorphology, word formation processes, Booij's Construction Morphology (CM), morphological schemas 


\section{List of Phonetic Symbols:}

\begin{tabular}{|c|c|}
\hline$\&$ & $/ \mathrm{R} /$ \\
\hline 1 & /a:/ /ā:/ \\
\hline ب ب & $/ \mathrm{b} / / \mathrm{p} /$ \\
\hline$ت$ & $/ \mathrm{t} /$ \\
\hline$\dot{H}$ & $/ \theta /$ \\
\hline ج & $/ \mathrm{g} /, / 3 /, / \mathrm{d}_{3} /$ \\
\hline$\tau$ & $/ \mathrm{h} /$ \\
\hline$\dot{\tau}$ & $|\chi|$ \\
\hline د & $/ \mathrm{d} /$ \\
\hline$\dot{j}$ & /ð/ \\
\hline J & $/ \mathrm{r} /$ \\
\hline$j$ & $|z|$ \\
\hline س & $/ \mathrm{s} /$ \\
\hline ش & $/ \mathrm{J} /$ \\
\hline ص & $/ \mathrm{s} /$ \\
\hline ض & /ḍ// \\
\hline$b$ & $/ \mathrm{t} /$ \\
\hline ظ & /TH/, /Z/ \\
\hline$\varepsilon$ & $/ \mathrm{S} /$ \\
\hline$\check{\varepsilon}$ & $/ \mathrm{y} /$ \\
\hline ف & /f/ \\
\hline ق & $/ \mathrm{q} /$ \\
\hline ك5 & $/ \mathrm{k} /$ \\
\hline J & $/ 1 /$ \\
\hline 5 & $/ \mathrm{m} /$ \\
\hline ن & $/ \mathrm{n} /$ \\
\hline 0 & $/ \mathrm{h} /$ \\
\hline 9 & /w/ /u:/ /o:/ \\
\hline s & /y/ /i:/ /ee/ \\
\hline 5 & $/ \mathrm{a} / / \overline{\mathrm{a}} /$ \\
\hline 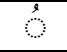 & $/ \mathrm{u} / / \mathrm{o} /$ \\
\hline अ & $/ \mathrm{i} / / \mathrm{e} /$ \\
\hline
\end{tabular}

List of Abbreviations:

$\mathrm{CxG}$ Construction Grammar

CM Construction Morphology

C Consonant

V Vowel

MSA Modern Standard Arabic

CA Colloquial Arabic

EA Egyptian Arabic

SA Standard Arabic 
$\underline{\text { Pal (Solar and Lunar) }}$

Solar Letters

\begin{tabular}{|c|c|c|c|}
\hline The trader & Pat-ta:zir & التاجر & $ت$ \\
\hline $\begin{array}{l}\text { The } \\
\text { clothing }\end{array}$ & 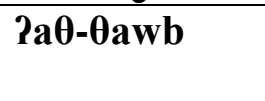 & الثوب & $\dot{\Delta}$ \\
\hline The house & Pad-da:r & الدار & $د$ \\
\hline The gold & ?að-ðahab & الذهب & $\dot{j}$ \\
\hline The man & 2ar-rāzul & الرجل & $\jmath$ \\
\hline The flower & Paz-zahrāh & الزهرة & $j$ \\
\hline The fish & Pas-samak & السمك & س - ( س \\
\hline The sun & Paf-jams & الثمس & ش ش \\
\hline The chest & Paș-sẹādr & الصدر & ص \\
\hline The guest & Paḍ-ḍāyf & الضيف & ض \\
\hline The student & Paț-țā:lib & الطالب & $b$ \\
\hline $\begin{array}{l}\text { The } \\
\text { injustice }\end{array}$ & PaTH-THulm & الظلم الظم & $\dot{b}$ \\
\hline The meat & 2al-lahm & اللحم & $J$ \\
\hline The star & Pan-nazm & النجم & ن \\
\hline
\end{tabular}

(Essentials of Arabic Grammar, 2008)

Lunar Letters

\begin{tabular}{|c|c|c|c|}
\hline $\begin{array}{l}\text { The } \\
\text { mother }\end{array}$ & 2al-umm & الأم & أ \\
\hline The door & 2al-ba:b & الباب & ب ب \\
\hline $\begin{array}{l}\text { The } \\
\text { garden }\end{array}$ & 2al-zannah & الجنة & ج \\
\hline $\begin{array}{l}\text { The } \\
\text { donkey }\end{array}$ & Pal-ḥima:r & الحمار & $\tau$ \\
\hline The bread & 2al- $\chi$ ubz & الخبز & $\dot{\tau}$ \\
\hline The eye & 2al-\{ayn & العين & $\varepsilon$ \\
\hline The lunch & Pal-yada:? & الغذاء & $\dot{\varepsilon}$ \\
\hline $\begin{array}{l}\text { The } \\
\text { mouth }\end{array}$ & Pal-fam & الفم الفم & فت \\
\hline The moon & Pal-qāmār & القمر & ق \\
\hline The dog & Pal-kalb & الكلب & 5 \\
\hline The water & 2al-ma:? & الماء ل الم & 5 \\
\hline The boy & Pal-walad & الولا ل الو & 9 \\
\hline The air & Pal-hawa:? & الهواء & D \\
\hline The hand & Pal-yadd & اليا & ى \\
\hline
\end{tabular}




\subsection{Introduction:}

This paper examines the varied factors that affected a number of Egyptian place names till they acquired their currently used forms. The analysis is divided into two main parts. The first part sheds light on the place names that were borrowed from old Egyptian languages such as Ancient Egyptian and Coptic. The second tackles the Egyptian place names that emerged after the Arab Advent in Egypt. In order to achieve this goal, the paper makes use of the concepts and tools of Booij's (2005) model of Construction Morphology (CM), under the umbrella of sociomorphology. By incorporating these tools, the researcher analyzes the forms of some of the place names used in Egypt to reveal the various socio-morpho-phonological alterations, whenever detected, that these place names have undergone in order to reach their present status.

\subsubsection{The Scope and Aim of the Paper:}

This paper is an attempt to investigate selected Egyptian place names and to demonstrate how such names have been affected by various social and linguistic factors. The linguistic outcomes of contact among Egyptian people i.e. the Copts and other speech communities such as Arabic, fall within the realm of this research. However, the focus is mainly dedicated to names of Arabic origin.

The goal of the study is to shed light on the socio-morphophonological changes and alterations of Ancient Egyptian, Coptic, and Arabic place names to reach their currently used forms, under the fabric of CM. Moreover, another essential aim is to find the schemas of these words, as schemas form an integral part of CM.

\subsubsection{Research Questions:}

This research endeavors to answer the following questions:

1) How are current Egyptian place names structured?

2) What are the linguistic outcomes that resulted from the contact between Arabic and other speech communities in Egypt with regard to Egyptian place names?

3) How were loanwords affected after being integrated within the EA language inventory? 
4) How can the theory of Construction Morphology (CM) be applied to Egyptian place names? Is it an adequate tool or does it manifest certain deficiencies as far as the data are concerned?

5) Can the schemas developed by Booij be applied to the Arabic language context or should the researcher develop new ones, specific to the Arabic word formation processes?

\section{Review of Literature:}

\subsection{Sociolinguistics:}

According to Trudgill (1984), sociolinguistics is an area of study that tackles the relation between language and society. $\mathrm{He}$ argues that this science encompasses many other topics such as social dialects, language attitudes, and language change. Therefore, many researchers in sociolinguistics would address such topics as linguistic variations that societies witness. He further states that sociolinguistics is a branch of applied linguistics that examines the interaction between language and society. Consequently, through conducting a sociolinguistic study, a researcher would be able to reach a full understanding of both the nature of language, especially language variation, as well as the nature of society.

One of the main concerns of sociolinguistics is how the use of language varies according to different social factors. As Bucholtz and Hall (2008) point out: "the development and spread of sociolinguistics ... has created an interdisciplinary foundation for the study of language, culture and society"(p.403). This means that this field of study is connected to many other fields, one of which is contact linguistics. Hence, since the present research endeavors to depict the social influence of contact on the morpho-phonology of some of the Egyptian place names, contact linguistics will be tackled in this study.

\subsubsection{Contact Linguistics and Sociolinguistics:}

The term contact linguistics was first introduced at the First World Congress on Language Contact and Conflict, held in Brussels in June 1979 (Winford, 2003, p. 9). Hickey (2010) elucidates that "contact studies is a field of linguistics which has been the subject of increasing interest in the past few decades" (p.1). Sankoff (2001) adds that "language contact is part of the 
social fabric of everyday life for hundreds of millions of people the world over"(sic) (p. 638).

Mello (2014) defines contact linguistics as "an interdisciplinary area of investigation that draws from different linguistic subfields, such as second language acquisition, sociolinguistics and theoretical linguistics, among others, besides taking into account historical and cultural theories" (p.409). Therefore, any language can be subject to change, and this change results from the contact among languages. For example, some sounds are introduced into a certain language inventory where these sounds did not originally exist. For instance, Egyptian Arabic (EA) makes use of the $/ v /$ sound (i.e. in villa), which is not a phoneme in Arabic, yet is rendered due to its contact with other languages (Bishai, 1961, p. 175).

\subsubsection{The Subject Matter of Contact Linguistics:}

Winford (2003) states that the main aim of contact linguistics is to examine the different "situations of contact between languages, the phenomena that result, and the interaction of linguistic and external ecological factors in shaping these outcomes". Therefore, linguists who are interested in contact linguistics are mainly concerned with investigating the different kinds of "mixture, change, adaptation, and restructuring that result from interaction between (the users of) different languages". He further mentions that this field deals with all the linguistic consequences of contact. These consequences include "phenomena of simplification" of the original form (p. 5).

According to Thomason (2001), contact is the reason behind any linguistic change that could have never occurred; if it were not for a specific "contact situation" (p. 62). This demonstrates that the contact between any two languages is the motive behind the linguistic alterations that languages can undergo. In other words, if there were no contact between languages, linguistic change would have never taken place. Similarly, Siemund (2008) professes that "languages can influence one another in a situation of contact" ( $\mathrm{p}$. 3 ). He proclaims that language contact is affected by three major factors i.e. the "social parameters" of contact, the various linguistic levels involved in the situation such as the phonology, morphology, syntax ...etc., and the overall structure of the languages in contact. 
He also stresses the fact that speakers are the core of the contact process.

To sum up, contact linguistics is one of the fields that are based upon the notions of sociolinguistics. This subfield of sociolinguistics is essential for this study to meet its goals. In other words, the contact between Arabic and other old languages that were used in Egypt such as Ancient Egyptian and Coptic had its impact on forming the Egyptian place names under analysis.

\subsubsection{Substrata and Superstrata Influence:}

According to Izzo (1975), the terms substratum and superstratum were first used to identify two different kinds of language contact. Wertburg (1943) explains "A superstratum" as "an invading group that blends into another group already inhabiting a territory and speaking another language". When the original inhabitants give up their language and shift to the new dominating one, their language is referred to as a substratum. Consequently, the new language is called a superstratum (as cited in Izzo, 1975, p. 2). Hence, Coptic was the substratum in Egypt after the Islamic Advent, and Arabic became the superstratum.

\subsubsection{Diglossia and vernacular forms:}

Another important concept in language contact is that of diglossia. The term diglossia is derived from the French word 'diglossie'. It was first introduced by Ferguson (1959). He states that "in many speech communities two or more varieties of the same language are used by some speakers under different conditions" (p. 232). Therefore, this definition indicates that the two varieties must stem from one single language. However, to Sayahi (2014), the scope of the term'diglossia' has widened since the mid-twenieth century in order to be applicable to a number of linguistic situations around the world. These situations encompass the "contact between varieties of the same language, languages belonging to the same family, or distant languages" (p. 1). Nevertheless, the term is used in the current paper in its traditional sense.

According to Yule (1996), 'diglossia' as a term is used to:

describe a situation in which two very different varieties of language co-exist in a speech community, each with a distant range of social 
functions. There is normally a 'High' variety, for formal or serious matters, and 'Low' variety for conversation and other informal uses. (p.246)

Ryding (2005) explains that each area in the Arab world has its own spoken vernacular that coexists with the Arabic standard variety. Therefore, there is not a "standard speech norm" for everyday life in Arabic. In other words, Arabs are fluent in at least one vernacular form. She considers this vernacular form to be their mother tongue. She also refers to this process of the "coexistence of two language varieties, the everyday spoken vernacular and a higher literary form" as "diglossia". She further describes the vernacular speech to be "more flexible and mutable" than the written one. This is because "it easily coins words, adapts and adopts foreign expressions, incorporates the latest cultural concepts and trends, and propagates slang" (p.5). This means that vernaculars are more productive, creative and richer than standard varieties. Thus, the current study examines present-day colloquial EA place names, and the social factors that led to their change, to be in their current forms. Hence, the researcher has chosen Socio-morphology as the broader framework of analysis, under which the tools of CM are deployed.

\section{Morphology:}

According to Yule (1996), the term morphology was first used in biology. It has a Greek origin: 'morph-' which means shape or form. Thus, it means "the study of forms". He further states that since the middle of the nineteenth century, this term has been used to address the basic elements used in a language (p. 75). Hence, morphology is the study of the internal structure of words and how they are formed (Aronoff and Fudeman, 2005). Morphological analysis is considered to be one of the basic linguistic analyses; since it paves the way for further types of analyses. The analysis in this study is conducted under CM, which is explained under the section of the framework of the study.

\subsection{Socio-morphology:}

Socio-morphology is a recent field of study. To the researcher's knowledge, limited literature can be found in this area in particular. According to Beeman (1986), Socio-morphology is a branch of sociolinguistics. It is mainly concerned with examining the different morphological forms within their social context. Furthermore, this field of study tackles the use of the adequate 
word forms in the suitable context within which the speakers are involved. Therefore, morphological variation is shaped to fit the needs of the different social situations (p.132). Danesi (2015) explains that "morphological structure often encodes differences in social roles". For example, the English language includes "lexical doublets" like 'waiter' and 'waitress' in which the -ess suffix has a "specialized meaning" (pp. 57-58), i.e. gender based distinctions in a language.

\subsection{Arabic Non-concatenative Morphology:}

According to Booij, Lehmann \& Mugdan (2000), Arabic morphology is referred to as /şārf/. The word /şārf/ literally means 'divert or turn'. A related term is /taşri:f/, which means 'drainage, change, or distribution'. The term /tasri:f/ can be referred to as "morphologization". In Arabic, both terms 'şārf' and 'taşri:f' are used interchangeably to refer to morphology (p. 68).

Arabic morphology is considered to be systematic in its approach. It takes its basis from the notion of root ( $\mathrm{Pa} s \mathrm{l} 1 / 3 i z r)$ and non-root or added (za:Pid) elements. On the one hand, the root is usually consonantal and can be represented by the template (f.S.l), which indicates doing an action. The added or the non-root, on the other hand, is most of the time consonantal in nature too, and as is clear from its name, it includes elements that are not part of the root. Apart from the root and non-root, there are vowels, which have a morphological form called al-wazn, 'measure' (Booij etal., 2000, pp. 67- 68).

Morphologically speaking, Arabic is a non-concatenative language. According to Kramer (2007), non-concatenative morphology is one of the most remarkable properties of a number of Afroasiatic languages such as Modern Hebrew, Coptic, and Arabic. Such languages tend to insert "an affix" in the consonantal pattern of a root word. This affix is usually "vocalic" in nature, i.e. it includes vowels. Thus, the stem of a content word in Arabic has three discontinuous morphemes: the consonantal root, which is the basic lexical unit of the language, the templatic pattern into which the consonantal root is inserted, and the vowels, or "the vocalic melody" of a word (Watson, 2002, p. 126).

Ryding (2005) proposes a definition for the Arabic word root. She states that"a root is a relatively invariable discontinuous bound morpheme, represented by two to five phonemes, typically three consonants in a certain order, which interlocks with a pattern to form a 
stem, and which has a lexical meaning" (p. 47). She further identifies a pattern as:

A pattern is a bound and in many cases, discontinuous morpheme consisting of one or more vowels and slots for root phonemes (radicals), which either alone or in combination with one to three derivational affixes, interlocks with a root to form a stem, and which generally has grammatical meaning. (p.48)

Examples of Arabic verbal patterns are:

I- fạ(a,u,i)l-a as in 'ðahab-a' (to go), kabur-a (to

grow up), and hazin-a (to become sad)

II- faY̧all-a as in 'faḍ̂āl-a' (to prefer)

III- fa:Yal-a as in 'ḥa:rāb-a' (to fight)

IV- PafCal-a as in 'Pahrāz-a' (to embarrass)

V- tafạall-a as in 'taḥarrāk-a' (to move).

(Gaddallah, 2000, p. 44)

\subsection{Word Formation Processes:}

Many processes are involved in generating new words in a language. Numerous scholars and researchers tackled these word formation processes. They are briefly presented as follows:

1- Coinage: coinage is the "invention of totally new terms". According to Yule (1996), coinage is considered to be "the least" productive word formation process in English. Examples of coined words are: 'aspirin', 'nylon' and 'zipper'(p. 64).

2- Compounding: Another word formation process discussed by Yule (1996) is compounding. He refers to this process as the "joining of two separate words to produce a single form" (p.65). He states that compounding is very frequent and productive in many languages around the world. According to Zapata (2007), a compound word is used as a single word, on both the grammatical as well as the semantic level. Furthermore, it is written in three different ways (open like 'toy store', hyphenated like 'flower-pot', or solid like 'Pickpocket') (p. 4). Compounding is also used in Arabic. For instance, the Arabic word 'rāisma:l' (capital) is an example of a compound that consists of the two words 'rā?s' (head) and 'ma:l' 
(money) to give a new word form with a unified meaning (Ryding, 2005).

3- Blending: This encompasses the combination of two words to create a new single form. According to Yule (1996), in order to create a new word form through blending, the beginning of one word is joined to the end of another. For example, there is the word "smog" from "smoke" and "fog" (P. 66). Blending is also used in Arabic. According to Al-Musa (1405 AH), "blending in Arabic involves "the formation of a new word from two or more than two words to the effect that the new word takes some phonic features from them all, and denotes them all in meaning" (p. 67 as cited in Mohammed, 2015, p. 1910). Examples of blening in Arabic are (قال حسبى الله ونعم الوكيل) حسبل (to say ḥasbiya-llāhu-waniYma-lwaki:1) and "sarman" (سار أثناء النوم) سرمن (to sleepwalk) (AlJarf, 2011, p. 165).

4- Clipping: This process takes place when a polysyllabic word is clipped or cut down to a shorter and simpler form. The English word 'fax' from 'facsimile' is an example of clipping (Yule, 1996, p. 66). According to Oriabi (2012), there are different types of clipping: back clipping ('demo' from 'demonstration'), fore clipping ('phone' from 'telephone'), middle clipping ('fridge' from 'refrigerator'), complex clipping ('inter pol' from International Police'), and truncation that is used to form personal names ('Sue' from 'Suzan') (pp. 4-6). Clipping is also used in Arabic. It has different names. One of these names is "partition إجتزاء". This process is "used to maintain unstrained and easy pronunciation of ألا تا فا بلى (Pala ta fa bala for ألا تفعل فابلى افعل (don't do it, yes you can do it) is an example of clipping in Arabic (Sibawayh, 1985, p. 233 as cited in Oriabi, 2012, pp. 11-12).

5- Backformation: According to Yule (1996), backformation means that "a word of one type (usually a noun) is reduced to form another word of a different type (usually a verb)". The verb to 'donate' (from donation) is an example of backformation (p. 67). Examples of backformation in Arabic are words like "/talfaz-a/ (v.) "تلفز from /telifizio:n/ (n.) تليفزيون (TV), and /barmāga/ (v.) برمج (prog) from /berna:meg/ (n.) برنامج (program), and /qānnanna/ (v.) قتن (1) from /qā:nu:n/ (n.) (law) (Al Jarf, 2011, p. 166). 
6- Derivation: According to Yule (1996), derivation is "the most common word-formation process to be found in the production of new English words" (p. 69). This process mainly relies on the use of the affixes like "un-, mis-, pre-, -ful ..." that occur in words like (untidy, misfortune, prejudge, and beautiful). Such prefixes and suffixes either change the meaning or the syntactic category (they may change both) of the words they are attached to and are called derivational affixes (Zapata, 2007, p. 2).

Derivation takes place in Arabic, yet in a somehow different way. Ryding (2005) notes that Arabic makes use of "introflection" or "ablaut" in order to generate more words from a base form. This process includes a "word-internal vowel change that affects both the meaning as well as the grammatical function of the word". For example, Arabic words like 'kita:b' (book), 'kutub' (books), and 'kutib-a' (was written) are all derived from the base verb 'katab-a' (to write) by means of introflection (p. 46).

7- Reduplication: According to Zapata (2007), reduplication is a process that encompasses "the repetition of all or of part of a root or stem word". Reduplication has two major types, i.e. complete or total reduplication and partial reduplication. In complete reduplication, on the one hand, the whole root or stem is replicated. In this case, the new word is a repetitive compound. In partial reduplication, on the other hand, a sole part of the root or stem is replicated (p. 6). Examples of reduplication in EA are: the verbs /fat-fit/ from Fattat-a (to break into tiny pieces), and / $\mathrm{Sam}-\mathrm{Sem} /$ from / Jamm-a/ (to sniff) (El Zarka, 2015, p. 2).

8- Eponymy: According to Zapata (2007), "eponymy is the process by which a number of words for places, inventions, activities, etc. have been derived from (or based on) the proper names of persons somehow connected with such places, inventions, activities, etc.". For instance, we have "Washington D.C." for George Washington, "Watt" after James Watt and "tsar" and "Kaisar" for Julius Caesar (p. 14). Some Arabic place names are formed through eponymy.

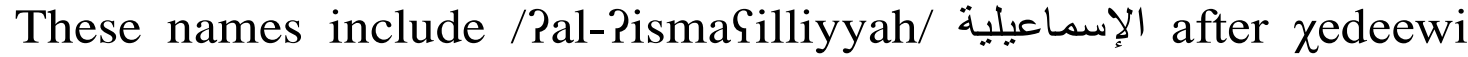
Ismail (Ramzy, 1994, sec. 2, part 2. P. 80) and /Pal-Faruq(P)iyyah/ after king Farouk I (Ramzy, 1994, sec. 2, part 1, p. 99). (See more examples in table 11)

9- Base Modification: According to Haspelmath and Sims (2010), base modification is "a collective term for morphological patterns in which the shape of the base is changed without adding segmentable material". 
Therefore, "it is often easiest to describe non-concatenative patterns as results of processes or operations that apply to a base form" (pp. 35-36). Examples of base modification by derivation in Arabic are: /Zulm/, /Zā:lim/, /māZlu:m/,...etc. (Mangrio, 2016, p.58).

10- Borrowing: According to Yule (1996), borrowing is one of the most productive ways of forming new words in English. He defines borrowing as "the taking over of words from other languages". He also notes that borrowing has led to the emergence of another word formation process i.e. loan translation or calque. "In this process, there is a direct translation of the elements of a word into the borrowing language". For instance, the English word 'superman' is a loan-translation of the German word'übermensch'(p. 65).

\subsubsection{Arabic Loanwords:}

Arabic language is flexible enough to incorporate many terms and expressions from other languages. Many of these forms are assimilated to suit the Arabic phonological as well as morphological norms. Prihantoro (2009) states that a loanword can coexist with the native words. In order for a loanword to be integrated into the borrowing language, some modifications and alterations must be applied. These modifications involve different word formation processes. He further adds that the main purpose of borrowing words is the gap or absence of equivalents to the borrowed expressions. Khrisat and Mohamed (2014) mention that "[b]orrowing in Arabic is a phenomenon that comes about as a result of ... the urgent need for expanding the Arabic lexicon in order to meet the exigencies in various fields of modern life" (pp. 134-35).

\subsubsection{Arabization:}

The word 'Arabize' (or "ta9ri:b") means "to be Arabic in form, style, character, or to bring under Arab influence or control" (Khrisat\& Mohamed, 2014). Therefore, "Arabization is a process that localizes a foreign text or a term and reshapes it to match Arabic mentality" (p. 135). According to Bueasa (2015), an Arabized loanword is the one that is "fully-assimilated" to the Arabic morpho-phonological system (p. 2). Therefore, borrowed words that do not undergo phonological or morphological changes are regarded as "foreign" (p. 3).

Khrisat and Mohamed (2014) argue that this term means "transliteration". It involves writing any letters that have no Arabic equivalents using the closest letters to Arabic pronunciation or to the Arabic sound system. The above definition demonstrates that Arabized 
words are used as if they were originally Arabic words. Hence, new words are derived from them. Thus, the process of Arabization aims at making use of foreign word forms and expressions into the Arabic language, after applying some phonetic or morphological variations when necessary.

According to Khrisat and Mohamed (2014), in order to Arabize a certain word, many processes take place. These processes include sound dropping, adding, deleting, replacing a letter with another, or changing the manner of articulation. Arabic "has borrowed words from other languages and Arabized others". This means that the Arabic language has probably expanded its vocabulary either through adopting the borrowed forms as they are or by internal restructuring of these forms (p. 134). This has also occured to some of the SA Arabic forms examined under the current study, which are explored using CM.

\section{The Theoretical Framework adopted in this Paper: 3.1. Construction Grammar ( $\mathbf{C x G})$ :}

Construction grammar $(\mathrm{CxG})$ is one of the recent approaches in linguistics, which sprang out of the field of cognitive linguistics. The main concept behind this theory is that constructions are the basic units of language (Goldberg 1995). El-Zawawy (2009) states that "constructions are considered the starting point for linguistic analysis on all levels" (p.5). This means that constructions should be central to all linguistic analyses.

The basic notion behind all constructionist approaches is that "[c]onstructions are stored pairings of form and function, including morphemes, words, idioms, partially lexically filled and fully general linguistic patterns" (Goldberg, 2003, p. 219). In other words, "a construction is a pairing of form and meaning". A very crucial issue about this form-meaning pairing is that it cannot always be derived from any general rules of language, or from the components of the pair. Furthermore, when there is an agreement in a language community on this form-meaning pairing, this pairing becomes a convention of that particular language community. This is referred to as "conventionalization" (Booij, 2010, pp. 1-2). According to Broccias (2006), "a linguistic unit is conventional if it is shared by a substantial number of individuals" (p.3).

\subsubsection{Construction Morphology (CM):}


In his model of Construction Morphology, Booij (2005) argues for a "hierarchical lexicon consisting of schemas of various degrees of abstractness" (Gurevich, 2006, p. 33). According to Booij (2010a), "the theory of construction morphology (CM) aims at better understanding of the relation between syntax, morphology, and the lexicon, and of the semantic properties of complex words" (p. 1). This means that, like Construction Grammar, construction morphology treats all the grammatical levels on an equal basis. In his work, Booij (2010b) has focused on some concatenative languages such Dutch and English. However, he states that verbal roots in Semitic languages "may appear in a number of different ... templates with specific patterns of consonants and vowels, sometimes with a prefix" (p. 4).

Construction Morphology, as developed by Booij, regards the word as the starting point for morphological analysis. He considers each word to be "a linguistic sign, a pairing of form, and meaning". Each word consists of three types of information (phonological, morphosyntactic, and semantic) and morphology tackles all of them. This is identified as "the tripartite parallel architecture of the grammar" (Jackendoff, 2002, 2007). Thus, "a word is a complex piece of information, and morphology deals with the systematic pairing of form and meaning at theword level". This information is expressed through morphological schemas. Booij also proclaims that the various word formation processes can be represented as "constructional schemas" (Booij, 2010, pp. 3-8).

\subsubsection{Schemas:}

Construction morphology follows a word-based approach in word analysis. In this approach, the word is the starting point of analysis. Concerning this point, Booij (2010) holds a comparison between sets of words like the following:

$$
\begin{array}{cc}
\text { (1a) bald } & \text { (1b) baldness } \\
\text { big } & \text { bigness (p. 1) }
\end{array}
$$

Through comparing the words in (1a) with those in (1b), Booij concludes that there is a formal distinction between the two columns of words. Such a distinction in form is related to the meaning of the words. The suffix -ness in (1b) indicates the property or state expressed in the adjectives in (1a). Thus, the word awareness can be expressed as follows: 


\section{[[aware]A ness]N (Booij, 2010, p. 1).}

Consequently, the words in (1b) can be represented by the following abstract schema:

\section{[[X]A ness]N 'the property/state of $\mathrm{A}^{\prime}$}

In this schema, $\boldsymbol{X}$ is a variable, and this slot can be filled with any adjective (Booij, 2010, p.2).

Such schema is a generalization about the form and meaning of the already existing English adjectival nouns ending in -ness. It also paves the way for more adjectival nouns to be formed in the same manner. In other words, a new noun can be formed by replacing the variable $\mathrm{X}$ with a real adjective. According to Booij (2010), in CM, such constructions are identified as "constructional idioms" at the word level, which are schemas "in which one or more positions are lexically fixed". Therefore, Arabic nouns ending in the feminine suffix -iyyah can be considered as constructional idioms too since they have one fixed part i.e. the suffix. Such nouns will be discussed in table (11) below. This fixed slot can also be filled by other syntactic units such as prepositions (Ex: year after year or N. after N. meaning Ns in succession) where the prep. slot is fixed, yet the $\mathrm{N}$ slot is varying (p. 4).This type is also represented in the data under study in words like: / $/ i z a h /, / k a \overline{f r} /$, etc.

Translating Koefoed (1993) definition of naming, Booij (2009a) states that "naming is creating a link between an expression and a concept. The expression is often a word, but can also consist of more than one word". Therefore, "the naming function is not restricted to words: certain types of phrases can also function as names". He further notes that "phrases used as names are often conventional expressions and hence lexical units" (pp. 219-20). Moreover, he proclaims that such constructions are used widely in European languages, and provided many examples of Dutch, Greek, Italian, French and English phrases that function as names. Examples of phrasal names or compounds include the NN Dutch compounds, and the N+NP constructions (Booij, 2009a, p. 224). English examples comprise: "NN book shelf, desk top, towel rack"; "VN drawbridge, pull tab", "PN afterthought, overdose, inland" , and "AN blackbird, greenhouse", (Booij, 2010, p.4), or the A+N English expressions 'blue cheese' and 'modern art' (Jackendoff (1997, 2002); Sadler \& Arnold (1994) as cited in Booij, 2009a, p. 226). In addition 
Booij (2013) agrees with Bauer's (2009) statement concerning compounding as: "the most common type of word formation in the languages of the world is compounding" (as cited in Booij, 2013, p. 4).This fact is also clear in the data under study.

\subsubsection{Default Inheritance:}

According to Booij (2012), "morphological schemas are acquired on the basis of a set of memorized complex words". In other words, a native speaker of a particular language develops schemas on the basis of "the fully specified words" s/he has learnt. An example is the deverbal nouns ending in -er such as 'teacher' and 'baker'. He further argues that "after sufficient exposure to a set of such words, the schema for the deverbal nouns in -er such as baker and writer can be grasped" (p. 1). Thus, once individuals have learnt a sufficient number of words of a certain type, they can deduce an abstract schema to expand this set of words.

The Core concept of default inheritance as defined by Booij (2012) is that a word inherits its properties from a dominating schema or constraint, unless these properties are identified in a different way. Thus, "the notion of inheritance has to be reinterpreted as 'motivation': a word formation schema motivates an individual complex word to the extent that it predicts its properties" (P. 6).

Booij (2010) defines the relationship between a schema and the words that follow this particular schema as a relationship of 'instantiation' (p. 2). Since words inherit their properties from the schemas they instantiate, word formation schemas motivate the existence of new complex words on the basis of the already existing ones. Therefore, "the relation between a schema and its dependents, the individual lexical items, is one of motivation" (Booij, 2012, p. 11).

\subsubsection{Analogy:}

Another crucial point that is raised by Booij (2009b) is the concept of "analogy". For example, the political scandal of Watergate gave rise to forming similar compound constructions using the suffix -gate. Thus, whenever there is a political or personal scandal, the suffix -gate is used to denote this scandal. "This looks like a clear case of analogical word formation"; and once 
language users notice "the commonality" of this component in forming compounds, they start to produce words in the same way (p. 2).

Similar schemas to the above can be applied to countless Arabic place names; since many Egyptian place names include a fixed part that does not change such as the Arabic place names Pabu-Mājhu:r, Pabu-hamma:d, Pabu-Nabha:n, etc. These genitive constructions can be presented by the general morphological schema [Pabu $[\mathrm{X}] \mathrm{N}$.]. The $[\mathrm{X}]$ slot is a variable that can be filled by any noun to form an Egyptian place name, as would be discussed in table (8).

According to Booij (2009b), "the implication of assuming a hierarchical lexicon with different levels of abstraction is that this is not a matter of 'either/or'; there is analogical word formation, based on an individual model word, but there is also word formation based on schemas". However, schemas come first. In other words, speakers use schemas to create new word forms. Once there is a sufficient number of words carrying the same features, anlogy is made use of in order to generate more forms (p. 15).

\subsection{Some influential studies on construction morphology and socio-morphology:}

In his book entitled, language, Status, and Power in Iran (1986), Beeman addresses Persian socio-morphology. He tackles many notions peculiar to the Iranian society such as verbal inflections, pronominal systems, clitics, etc. He also deals with what he identifies as "language of ta@a:rof" i.e. the expressions utilized to flatter the hearer and self-humiliate the speaker. Beeman refers to this as "self-lowering and other raising". Similarly, in her paper, Nkamigbo (2012) attempts to explore an aspect of the Koring culture, i.e. the phenomenon of verbal greetings. To reach her goal, Nkamigbo deals with twenty-one types of greetings. She considers her study as a socio-morphological one, since she analyzes the various types of Koring greetings i.e. the morphological forms within their social contexts.

In her dissertation, Gurevich (2006) combines between Construction Grammar and Word-and-Paradigm morphology in order to develop the framework of constructional morphology. She argues that morphological and morpho-syntactic patterns should be dealt with as pairings of form and meaning i.e. constructions. 
Moreover, Tsujimura and Davis (2011) follow a constructional approach in analyzing Japanese innovative verbs that are derived from nouns of different origins such as Chinese, mimetics and proper names. In this paper, the researchers apply construction morphology, Booij's model (2005, 2009a, 2009b).

\section{Methodology:}

\subsection{The Corpus and Source of Data:}

The corpus of the current study includes 130 place names, derived from Al-Qamous Al-Gughraphiy, The Geographic Dictionary, by Mohamed Ramzy (1994). This work was first published in 1945. The deployed edition is divided into six volumes i.e. an appendix, section one that deals with places that no longer exist, and section two, which is divided into four parts (each part contains the place names of a number of governorates). The data of the study is derived from the second section of the dictionary. This dictionary is considered as a linguistic, historical, geographical as well as a social encyclopedia. Its volumes encompass a full account of all the Egyptian villages, towns, cities and governorates from the time of the Ancient Egyptians up to the year of publication, 1945.

In order to reach an accurate account of all the place names dealt with in the dictionary, Ramzy resorted to a number of references like Dali:l Albila:d Almesriyyah, A Guide to the Egyptian Cities, that was edited in (1224 AH) after the French Campaign in Egypt. Another essential reference is Ta:ri: $\chi$ Mohamed Ali, The History of Mohamed Ali (1228 AH). In his pursuit, Ramzy (1945) investigated other geographical references in addition to asking the elderly people about their villages and the neighboring ones. The entries of the dictionary are arranged in alphabetical order. Furthermore, under every entry, Ramzy (1994) provided the place name in its original form (this form is either transliterated in English or written in Arabic), whether Ancient Egyptian, Coptic or Arabic. At times, he discussed the origin of the name; while at other times he did not state the origin.

\subsection{Sampling, Methods, and Procedures:}

The researcher selected some words to be analyzed from the dictionary. Next, the words were transcribed, and a list of phonetic symbols was provided. However, since the vocalic systems of both 
Ancient Egyptian and Coptic were not presented clearly by Ramzy (1994), i.e. pronunciation key and description of vowels, the researcher resorted to works by current specialized Coptic writers, tracing similar phenomena. In addition, being extinct, and are no longer used to generate new schemas, these forms were merely represented using $\mathrm{CV}$ patterns (Consonants/vowels). Hence, no further analysis was provided for their schemas, as they fall beyond the scope of the theory followed in this study.

The analyzed EA place names were presented with their pronunciation in tables (each table may carry a different heading to suit the analyzed forms). Most notably, the selected places were grouped according to their word formation processes along with their schemas in paradigms, after providing suitable generalized schemas for these EA places of Arabic origins (SA). Next, the phonological and morphological alterations that have affected these terms were explained under the framework of Booij's theory of CM. It is to be noted that SA here is used to denote the high variety, since the range of the analysis of data is extended to cover the period when Arabic was initially used in Egypt. Moreover, the meanings of the analyzed place names were presented from Ramzy; otherwise they were given by the researcher. For this purpose and for checking the Arabic origins of the terms, baheth.net is frequently checked. This electronic search engine includes the following Arabic lexicons: Lisa:nu-l-SArāb, Maqāyi:su-l-Luyah, Al-siha:h fi-l-Luyah, Al-Qamu:su-lMuhi:t, and Al-Sababu-l-ða:Xir. However, at times the meanings are obscure, as would be pointed out, wherever encountered.

In order to develop a coherent morphological analysis of a language, the diachronic aspect of that language should be taken into consideration, as diachronic changes allow for deeper comprehension of the basis of language (Bybee, 2010). The study follows a synchronic-diachronic approach. According to de Saussure, the synchronic investigation of a language involves the actual forms used by speakers. He calls this the "reality of speakers". As for the diachronic study of a language, it examines "a series of events that modify it" (Mlinar, 2010). Therefore, both the original forms, i.e. diachronic and the current forms, i.e. synchronic, were examined in this paper to reveal whether specific language forms persisted or ceased to exist. Therefore, the researcher investigated the origin of the words under analysis, whether Ancient Egyptian, Coptic, or Arabic both historically and currently. 


\section{Analysis:}

This part is dedicated to analyzing the selected Egyptian place names. It is divided into two parts. The first part includes two subsections, the first of which tackles Arabized Ancient Egyptian place names, while the second subsection deals with Arabized Coptic Egyptian names. However, as noted in section 4.2, and owing to the researcher's limited knowledge of Ancient Egyptian and Coptic, extensive examination of these languages is not provided. The paper merely elucidates the archaic schemas of Egyptian and Coptic origins, being essential to the study of place names. The second part includes subsections of Arabic place names that were formed after the Arabic Advent in Egypt.

\subsection{Ancient Egyptian Morphology:}

According to Loprieno (1995), Ancient Egyptian is a nonconcatenative language that forms a branch of the Afroasiatic language family. Ancient Egyptian has passed through different phases (Early Egyptian, Middle Egyptian, Late Egyptian, and Coptic). It includes a number of emphatic consonants in addition to the voiced and voicelass ones. It also contains a limited number of vowels i.e. /a/, /i/, and /u/. Loprieno (1995) further notes that the morphological system of Ancient Egyptian differs from the other Semitic and Afroasiatic languages. $\mathrm{He}$ adds that Egyptian contains a large number of biradical (and possible monoradical) roots, which contradicts with the Semitic triradical root.

According to Loprieno (1995), "[t]he basic structure of an Egyptian word is a lexical root". This root consists of consonants or semi-consonants. Such consonants vary in number. In other words, the consonants forming an Egyptian root may range from one to four consonants. Through the insertion of a vocalic pattern to the root, a stem is formed. He considers this stem as the surface form of the root, which is the one that 'determines' the function or the part of speech to which a word belongs (p. 52).

In his discussion of reconstructing the phonological system of the Ancient Egyptian language, Loprieno (1997) argues that it is difficult to reconstruct the phonology of Ancient Egyptian; because of "the very nature of the writing systems: Hieroglyphs, Hieratic, and Demotic represent the mere consonantal skeleton of a word (and sometimes only a portion thereof) ... Semivocalic phonemes are rarely indicated, vowels practically never". Therefore, "the traditional pronunciation and 
transliteration of many hieroglyphic phonemes rest upon hardly anything more than scholarly conventions" (p. 431).

\subsubsection{Place Names of Ancient Egyptian Origin:}

These Ancient Egyptian place names show a number of morphophonological alterations that are explained in the table. Following CM, each word is going to be presented by a schema, which merely depicts the CV pattern, as it is written in English by Ramzy (1994).

\begin{tabular}{|c|c|c|c|}
\hline \multicolumn{4}{|c|}{ Table (1) } \\
\hline \begin{tabular}{lr|} 
Original & Forms \\
and & page \\
numbers & \\
\end{tabular} & $\begin{array}{l}\text { Phonological } \\
\text { Changes }\end{array}$ & Morpho-phonological Changes & EA Form and Its Schema \\
\hline $\begin{array}{l}\text { /bah-ti:t/بهتيت } \\
\text { (section 2, part } \\
\text { 1, p. 12) }\end{array}$ & $\begin{array}{l}\text { /bah-ti:t/> } \\
\text { /bah-ti:n/ > } \\
\text { /bah-ti:m/ }\end{array}$ & $\begin{array}{l}\text { Its name changed from bahti:t } \\
\text { to bahti:n and then to bahti:m } \\
\text { in the Ottoman era. } \\
\text { 1- These changes involve } \\
\text { replacing the dental /t/ with } \\
\text { the voiced alveolar nasal /n/. } \\
\text { 2- The second alteration } \\
\text { involves replacing the nasal } \\
\text { /n/ with the bilabial nasal /m/, } \\
\text { probably as a result of } \\
\text { progressive assimilation from } \\
\text { the bilabial /b/. }\end{array}$ & $\begin{array}{l}\text { /bah-ti:m/ بهتيم } \\
{[\text { [CaCCi:t] } \rightarrow \text { [CaCCi:n] }} \\
\rightarrow[C a C C i: m]\end{array}$ \\
\hline $\begin{array}{l}\text { Ber ba (sec. } 2, \\
\text { part } 4, \text { p. } 108)\end{array}$ & $\begin{array}{l}\text { /ber ba/ } \\
>/ \text { Pel-ber-ba/ }\end{array}$ & $\begin{array}{l}\text { 1- According to Ramzy, the } \\
\text { word 'ber' means home, and } \\
\text { 'ba' means spirit. The whole } \\
\text { phrase 'berba' means the home } \\
\text { of wisdom in Ancient } \\
\text { Egyptian. It refers to the place } \\
\text { where ancient Egyptians used } \\
\text { to learn science and } \\
\text { particularly theology. } \\
\text { 2- In order to construct this } \\
\text { place name, the Arabic } \\
\text { definite article is inserted and } \\
\text { the two forms are joined into } \\
\text { one form. }\end{array}$ & $\begin{array}{l}\text { /Rel-ber-ba/ البربا } \\
\text { Ca] } \rightarrow[\text { Pel- CeC Ca] }\end{array}$ \\
\hline $\begin{array}{l}\text { Shebro (sec. } 2, \\
\text { part } 1, \text { p. 12) }\end{array}$ & $\begin{array}{l}\text { /Jeb-ro/ } \\
/ \int \mathrm{ob}-\mathrm{ra} /\end{array}$ & $\begin{array}{l}\text { The vowel system of the } \\
\text { original form is altered i.e. the } \\
\text { /e/ changed into an /o/ and the } \\
\text { final /o/ changed into an /a/ }\end{array}$ & 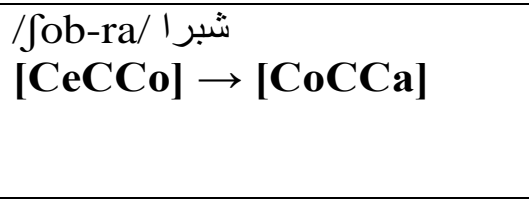 \\
\hline
\end{tabular}


The original forms of the few examples presented in the table are all bisyllabic. The Arabized forms follow the same pattern of the original forms. For example, both shebro and shobra follow the pattern CVC-CV, taking into consideration that the vowels have changed. Also, one Arabized place name makes use of the Arabic definite article ?al.

\subsection{Coptic and Arabic:}

This section is an attempt to show the alterations that some of the Coptic place names in Egypt have undergone under the influence of Arabic. According to Loprieno (1997), the alphabetical system of Coptic is drawn from Greek. Coptic has two major dialects i.e. 'Sahidic' (صعيدى) and 'Bohairic' (بحيرى). Sahidic is the dialect spoken in Upper Egypt, and it represents the language of "classical Coptic literature". It has been recorded since the $4^{\text {th }}$ century C.E. Bohairic, the dialect of the Coptic Church and liturgy, is the Coptic variety of the Nile delta, and it has been recorded since the $5^{\text {th }}$ century C.E.

Bishai (1961) notes that Coptic has possibly affected EA in a number of aspects. The following are the most significant ones:

1 - It is generally observed that in Coptic loanwords in Egyptian Arabic, Coptic /p/ is borrowed invariably as /b/ or /f/. For example, the Coptic place name mnpalo:t is rendered in EA as manfālo:t

2- Coptic loanwords with an /o:/ vowel are always borrowed into EA with /u:/ such as the Coptic /fo:t/ (towel), which becomes /fu:ța/ فوطة in EA.

Bishai (1961) adds that "Coptic did not influence Egyptian Arabic as much as it would be expected under normal conditions of bilingualism". He further argues that bilingualism between Coptic and Arabic was limited. In addition, Coptic may have had less prestige than Arabic and this did not allow much interference between both languages; since people always tend to use the more prestigious language (p. 182).

The following table presents some morphological changes that affected the consonantal pattern of the analyzed forms.

\subsubsection{Place Names of Coptic Origin:}

\begin{tabular}{|c|c|c|c|}
\hline \multicolumn{4}{|c|}{ Table (2) } \\
\hline $\begin{array}{l}\text { Original } \\
\text { Forms and } \\
\text { page } \\
\text { numbers }\end{array}$ & $\begin{array}{l}\text { Phonological } \\
\text { Changes }\end{array}$ & $\begin{array}{l}\text { Morpho-phonological } \\
\text { Changes }\end{array}$ & EA Form and its schema \\
\hline $\begin{array}{l}\text { Mnpālo:t } \\
\text { (this form is } \\
\text { provided by } \\
\text { Bishai }\end{array}$ & $\begin{array}{l}\text { /mnpālo:ț/ > >āfālo:ț } \\
\text { /mân }\end{array}$ & $\begin{array}{lr}1-/ \overline{\mathrm{a}} / \text { was added after } \\
/ \mathrm{m} / \text { possibly to break the } \\
\text { unallowed } \\
\text { consonant } & \text { cluster }\end{array}$ & $\begin{array}{l}\text { /mānfālo:ț/ منفلوط } \\
{[C \mathbf{C p a ̄ C o : C ] ~} \rightarrow[\mathrm{Ca} \mathbf{C} f \bar{a} C o: C]}\end{array}$ \\
\hline
\end{tabular}




\begin{tabular}{|c|c|c|c|}
\hline $\begin{array}{l}(1961) \text { as } \\
\text { velarization } \\
\text { is not } \\
\text { detected by } \\
\text { Ramzy } \\
\text { (1994, sec. } \\
\text { 2, part 4, p. } \\
\text { 78) }\end{array}$ & & $\begin{array}{l}\text { (according to Gadalla } \\
\text { CCC is not allowed in } \\
\text { EA }(2000, \mathrm{p} .11)) \text {. } \\
2 \text { - The medial bilabial } \\
\text { voiceless stop } / \mathrm{p} / \\
\text { changed into } \\
\text { labiodental } \\
\text { voicelessFricative/f/. } \\
\text { Hence, the voiceless } \\
\text { feature is maintained. }\end{array}$ & \\
\hline $\begin{array}{l}\text { Panouf (sec. } \\
\text { 2, part } 2 \text {, p. } \\
222)\end{array}$ & $\begin{array}{l}\text { /panu:f/ > } \\
\text { /menu:f/ }\end{array}$ & $\begin{array}{l}\text { 1- The initial voiceless } \\
\text { bilabial stop /p/ was } \\
\text { replaced by a voiced } \\
\text { bilabial nasal } / \mathrm{m} / \text {, being } \\
\text { another bilabial nasal } \\
\text { that matches the } \\
\text { following voiced nasal } \\
/ \mathrm{n} / \text {. } \\
2-\text { The vowel /a/ is } \\
\text { replaced by an /e/ in EA. }\end{array}$ & $\begin{array}{l}\text { /menu:f/ منوف } \\
\text { [paCu:C] } \rightarrow \text { [meCu:C] }\end{array}$ \\
\hline $\begin{array}{l}\text { semhout/ } \\
\text { (sec. 2, part } \\
4 \text {, p. 197) }\end{array}$ & $\begin{array}{l}\text { /semhu:t/ > } \\
\text { /samhu:d/ }\end{array}$ & $\begin{array}{l}\text { 1- The /e/ sound changed } \\
\text { into /a/. } \\
\text { 2- The final voiceless } \\
\text { dental /t/ changed into its } \\
\text { voiced counterpart /d/. }\end{array}$ & 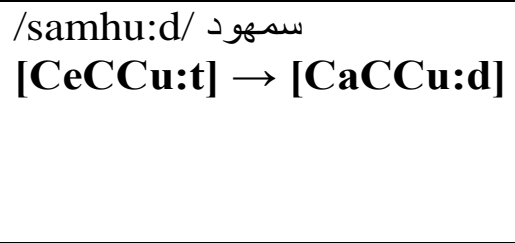 \\
\hline $\begin{array}{l}\text { Siout (sec. 2, } \\
\text { part 4, p. 25) }\end{array}$ & $\begin{array}{l}\text { /siyu:t/ > } \\
\text { /Rāsyu:ț/ }\end{array}$ & 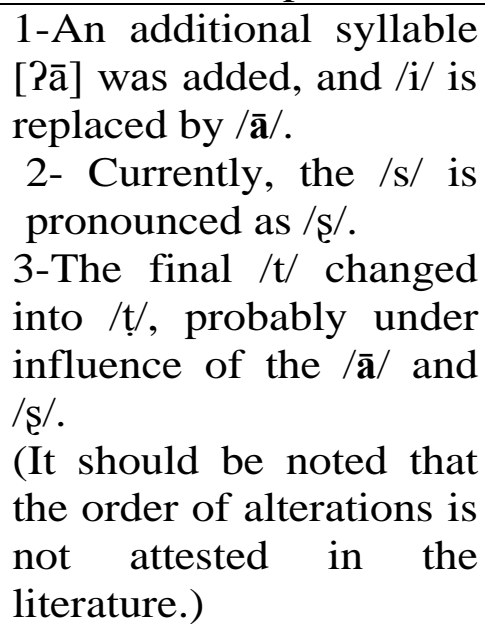 & 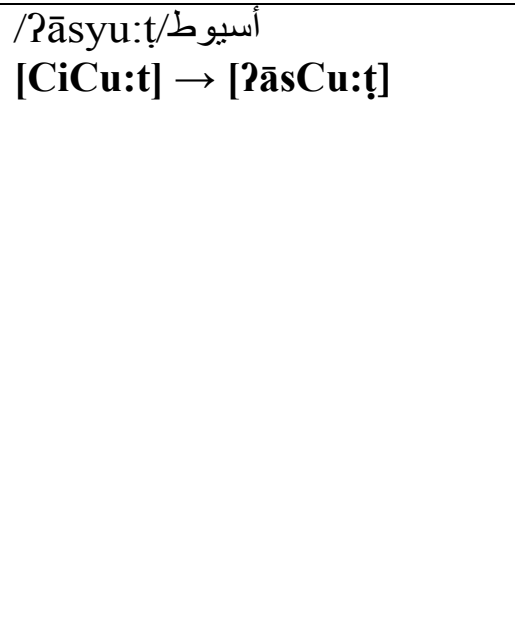 \\
\hline
\end{tabular}

The Coptic forms are either tri- or bisyllabic words. The Arabized forms follow the same canonical pattern of the original ones, except the last form (siout). The Arabized place name / $\mathrm{Pa} s y u: t /$ uses an additional syllable / $\overline{\mathrm{a}} /$ at the beginning of the word. It is noted that many Egyptian place names follow similar ways (adding an initial $/ \mathrm{Ra} /, / \mathrm{Ra} /$, or $\mathrm{Pe}$ ) to Arabize Coptic place names. Instances of such names include إسنيت from /swā:n/ (Ramzy, 1994, sec. 2 part 4, p. 216) and /Pesni:t/ أسوان from /seni:t/ (Ramzy, 1994, sec. 2 part 1, p. 19).

Egyptian place names of Coptic and Ancient Egyptian origins are formed through base modification. It can be noted that almost all the forms are simple words that have undergone internal modifications to their consonantal or vocalic patterns, 
without adding any segmentable parts. This cannot be considered derivation with respect to Ryding's (2005) notion of introflection; since not only the vocalic system is affected, but also the consonantal pattern.

Although the above data show some alterations that affect the consonantal as well as the vocalic patterns of the analyzed place names, there are no generalized schemas that govern place names of Ancient Egyptian or Coptic origin. It is possible that the above schemas were used during these eras to generate place names. Nowadays, they are considered archaic; therefore, they are beyond the scope of the present study. In other words, they are not used nowadays to create new place names, to the knowledge of the researcher.

\subsection{Place names of Arabic Origin:}

\subsubsection{Compounding:}

The following subsections all include instances of compounds, with differences that would be marked in every case. Moreover, such forms may include other word formation processes as would be noted, whenever detected. It is to be noted that some forms are suspected to be originally EA, yet for conformity, they are treated as SA, for lack of evidence.

\subsubsection{Compounds with Minyat $>$ Mi:t}

The following table includes place names that have undergone similar morpho-phonological changes. All these compounds used to have the word /minyah(t)/ منية, which was replaced by the word /mi:t/, the origins of which are contentious. According to Ramzy (1994) the original form of the word 'minyah' is the Coptic word 'timoni' (sec. 2, part, 1, p. 14), yet the meaning of both is unknown. However, the word /mi:t/ means road in Ancient Egyptian (cairodar.youm7.com). The final consonant in the word /minyah/ منية is called /ta:? marbu:țah/, which is pronounced as /t/ when followed by another word, but as $/ \mathrm{h} /$ when it occurs at the end of speech (Kayfa Tufarriq). The words in this table can be represented by the following schema:

$$
[[\text { minyat }][X] N .] \rightarrow[[m i: t][X] N .]
$$

where $\mathrm{N}$ stands for a proper noun, common noun, with or without / $\mathrm{Rel} /$ or with genitive like Pabu-N. The majority of the nouns of this schema are masc. sing proper names (9 names out of 17).

\begin{tabular}{|c|c|c|}
\hline \multicolumn{3}{|c|}{ Table (3) } \\
\hline $\begin{array}{c}\text { Original Forms } \\
\text { represented by } \\
\text { Ramzy and page } \\
\text { numbers }\end{array}$ & $\begin{array}{c}\text { Morpho-phonological } \\
\text { Changes }\end{array}$ & Current EA Form \\
\hline $\begin{array}{l}\text { /minyat nama/ منية } \\
\text { نما (sec. 2, part 1, } \\
\text { p. 58) }\end{array}$ & $\begin{array}{c}\text { /minyat nama/ > } / \text { mi:t } \\
\text { nama/ }\end{array}$ & ميت نما /mi:t nama \\
\hline $\begin{array}{l}\mid \text { /minyat halfa/ } \\
\text { منية (sec. 2, 2, } \\
\text { part 1,p. 58) }\end{array}$ & $\begin{array}{l}\text { /minyat halfa/ > /mi:t } \\
\text { halfa/ }\end{array}$ & $\begin{array}{l}\text { /mi:t halfa/ } \\
\text { ميت حلفا (halfa is the name of } \\
\text { a plant that grows in Egypt) }\end{array}$ \\
\hline منية /minyat rā:ḍi/ & /minyat rā:dì/ > /mi:t & /mi:t rā:ḍi/ \\
\hline
\end{tabular}




\begin{tabular}{|c|c|c|}
\hline $\begin{array}{l}\text { 1, p. 27) } \\
\text { 1, (sec. 2, part }\end{array}$ & rā:ḍi/ & $\begin{array}{l}\text { - masc. proper } \\
\text { noun }\end{array}$ \\
\hline $\begin{array}{l}\text { /minyat } \quad \text { Sa:sim/ } \\
\text { منية عاصم (sec. 2, } \\
\text { part 1, p. 27) }\end{array}$ & $\begin{array}{l}\text { /minyat } \text { Sa:sim/ }>/ \mathrm{mi}: \mathrm{t} \\
\text { ৎă:sem/ 1- the /a:/ is } \\
\text { replaced by an /ā:/ in } \\
\text { EA probably under the } \\
\text { influence of the } \\
\text { emphatic /s/. 2- the /i// } \\
\text { is replaced by /e/ in } \\
\text { EA. }\end{array}$ & $\begin{array}{l}\text { /mi:t Gā:sem/ } \\
\text { عاصيت مئ- masc. proper } \\
\text { noun }\end{array}$ \\
\hline $\begin{array}{l}\text { /minyat kina:nah/ } \\
\text { منية كنانة (section 2, } \\
\text { part 1, p. 48) }\end{array}$ & $\begin{array}{l}\text { /minyat kina:nah/ > } \\
\text { /mi:t kina:nah/ }\end{array}$ & $\begin{array}{l}\text { /mi:t kina:nah/ ميت كنانة } \\
\text { According to Ramzy } \\
\text { (1994), this name is derived } \\
\text { from the name of an } \\
\text { Arabian tribe called } \\
\text { kina:nah. It seems that its } \\
\text { people used to inhabit this } \\
\text { area. }\end{array}$ \\
\hline $\begin{array}{l}\text { /minyat g(3)a:bir/ } \\
\text { منية (sec. 2, } \\
\text { part 1, p. 105) }\end{array}$ & $\begin{array}{l}\text { /minyat } \mathrm{g}(3) \mathrm{a}: \text { bir/ }> \\
/ \mathrm{mi}: \mathrm{g}(3) \mathrm{a}: \text { ber/. (the } / \mathrm{i} / \\
\text { is replaced by /e/ in } \\
\text { EA.) }\end{array}$ & $\begin{array}{l}\text { /mi:t g(3)a:ber/ } \\
\text { جابر - masc. proper noun }\end{array}$ \\
\hline $\begin{array}{l}\text { /minyat habi:b/ } \\
\text { منية حبيب (sec. 2, } \\
\text { part 1,p. 105) }\end{array}$ & $\begin{array}{l}\text { /minyat ḥabi:b/ > /mi:t } \\
\text { ḥabi:b/ }\end{array}$ & $\begin{array}{l}\text { /mi:t habi:b/ } \\
\text { ميبيت حبيب masc. proper noun }\end{array}$ \\
\hline $\begin{array}{ll}\text { منية ركاب } & \text { rika:b/ }\end{array}$ & $\begin{array}{l}\text { /minyat rika:b/ }>/ \text { mi:t } \\
\text { reka:b/ (the /i/ is } \\
\text { replaced by an /e/ in } \\
\text { some EA dialects.) }\end{array}$ & 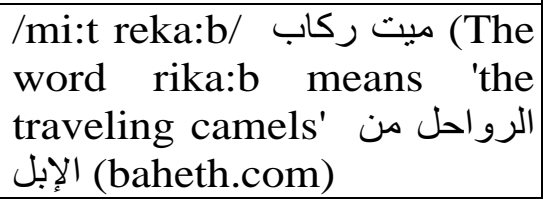 \\
\hline $\begin{array}{l}\text { /minyat hamal/ منية } \\
\text { حمل (sec. 2, part 1, } \\
\text { p. 105) }\end{array}$ & $\begin{array}{l}\text { /minyat hamal/ > /mi:t } \\
\text { hamal/ }\end{array}$ & $\begin{array}{l}\text { /mi:t hamal/ } \\
\text { ميت حمل }\end{array}$ \\
\hline $\begin{array}{l}\text { /minyat suhayl/ } \\
\text { منية سهيل (sec. 2, } \\
\text { part 1, p. 146) }\end{array}$ & $\begin{array}{l}\text { /minyat suhayl/ > /mi:t } \\
\text { seheel/ (the/u/ is } \\
\text { replaced by an /e/, and } \\
\text { the /ay/ is replaced by } \\
\text { /ee/ in EA.) } \\
\text { Sometimes, the /e/ is } \\
\text { elided. }\end{array}$ & $\begin{array}{l}\text { /mi:t s(e)heel/ ميت سهيل } 1 \text { masc. proper noun } \\
\text { man }\end{array}$ \\
\hline $\begin{array}{l}\text { /minyat yazi:d/ منية } \\
\text { يزيد (sec. 2, part 1, } \\
\text { p. 147) }\end{array}$ & $\begin{array}{l}\text { /minyat yazi:d/ > /mi:t } \\
\text { yazi:d/ }\end{array}$ & $\begin{array}{l}\text { /mi:t yazi:d/- masc. proper } \\
\text { noun ميزيديد }\end{array}$ \\
\hline 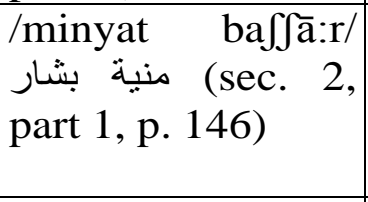 & 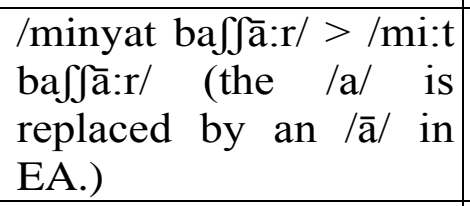 & 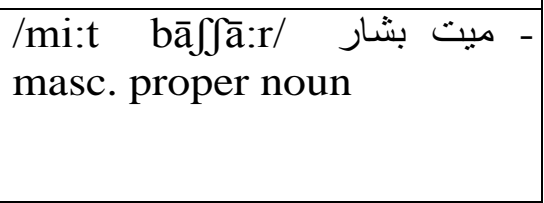 \\
\hline $\begin{array}{l}\text { /minyat Pisna/ منية } \\
\text { إسنا (sec. 2, part 1, } \\
\text { p. 177) }\end{array}$ & $\begin{array}{l}\text { /minyat Pisna > /mi:t } \\
\text { Pifna/ } \\
\text { The /i/ is replaced by }\end{array}$ & $\begin{array}{l}\text { /mi:t Pefna/ } \\
\text { ميت إشنا }\end{array}$ \\
\hline
\end{tabular}




\begin{tabular}{|c|c|c|}
\hline & $\begin{array}{l}\text { /e/ and the/s/ sound of } \\
\text { /Pesna/ is replaced by a } \\
/ S /\end{array}$ & \\
\hline $\begin{array}{l}\text { /minyat } \quad \text { qudayr/ } \\
\text { منية خُضَير (sec. 2, } \\
\text { part 1, p. 204) }\end{array}$ & $\begin{array}{l}\text { /minyat } \chi \text { udayr / > /mi:t } \\
\chi \text { udeer/ } \\
\text { The /ay/ is replaced by } \\
\text { /ee/ in EA. }\end{array}$ & 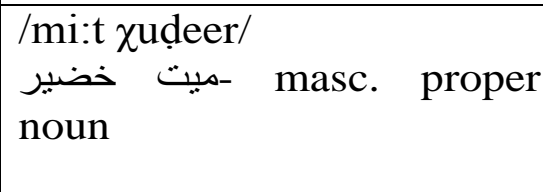 \\
\hline $\begin{array}{l}\text { منية } \\
\text { غمinyat yāmr (sec. 2, part 1, } \\
\text { p. 263) }\end{array}$ & $\begin{array}{l}\text { /minyat yāmr } />/ \mathrm{mi}: \mathrm{t} \\
\text { yāmr/ }\end{array}$ & $\begin{array}{l}\text { /mi:t yāmr/ } \\
\text { غميث origin of the name } \\
\text { is contentious and obscure }\end{array}$ \\
\hline 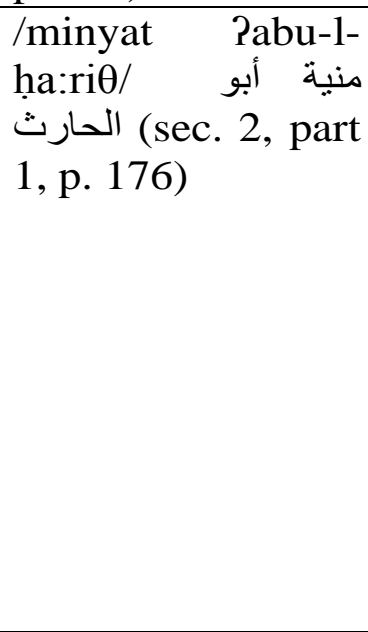 & 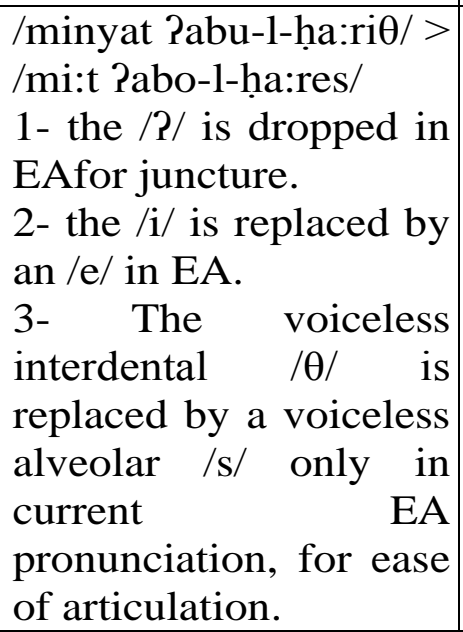 & $\begin{array}{l}\text { ميت أبو الحارث } \\
\text {-masc. proper noun }\end{array}$ \\
\hline $\begin{array}{l}\text { /minyat Pal-Ga:mil/ } \\
\text { pist (sec. 2, } \\
\text { part 1, p. 177) }\end{array}$ & $\begin{array}{l}\text { /minyat Pal-Sa:mil }> \\
\text { /mi:t-əl-Ga:mil/ } \\
\text { The glottal stop / } / \text { is } \\
\text { dropped in the } \\
\text { colloquial } \\
\text { pronunciation and a } \\
\text { weak /ə/ is inserted } \\
\text { instead of the /a/ of the } \\
\text { definite article. }\end{array}$ & 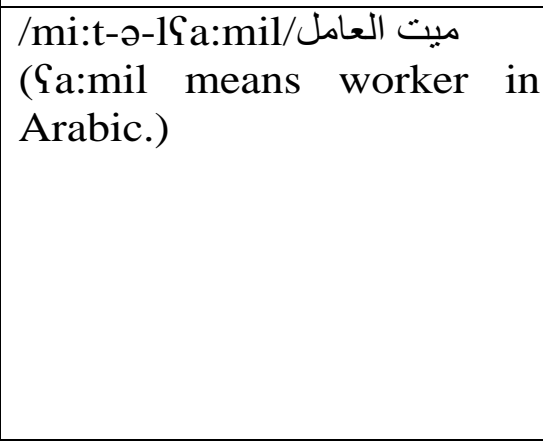 \\
\hline
\end{tabular}

\subsubsection{Compound or complex words with (Kāfr):}

The Following table discusses a different phenomenon. The place names included in this table are either compound or complex words that are genitive constructions. Trask (1993) defines the genitive as "a distinctive case form typically marking a noun phrase which serves a possessive role within a larger noun phrase" (p. 118). In Arabic, this is referred to as "Piḍdā:fah or annexation" (Gadalla and Abdel-Hamid, 2000, p. 3). Ryding (2005) considers annexation to be a case of nominal compounding in which a noun phrase is used to denote a noun (p. 101).

All of the nouns discussed here start with the word $/ \mathrm{kafr} />/ \mathrm{ka} f \mathrm{r} /$ that means "the small village"(baheth). Some of these place names used to have other names, as shown in the table, whereas others have only one form, the one mentioned in the table. It should be noted that sometimes a weak vowel i.e. /i/ or $/ \partial /$ is inserted at the juncture point to link between the components of the place names provided. The place names discussed in this table are majorly masculine proper names ( 9 out of 10). They can be schematized as follows: 
[[kāfr] [X]proper noun] $\leftrightarrow$ The small village of [X]

[[kāfr] [X]proper noun [Y]proper noun] $\leftrightarrow$ The small village of [X] [Y]

\begin{tabular}{|c|c|c|}
\hline \multicolumn{3}{|c|}{ Table (4) } \\
\hline $\begin{array}{l}\text { Original Forms } \\
\text { represented by } \\
\text { Ramzy and } \\
\text { page numbers }\end{array}$ & $\begin{array}{c}\text { Morpho-phonological } \\
\text { Changes }\end{array}$ & Current EA Form \\
\hline $\begin{array}{l}\text { /kāfr sali:m/ } \\
\text { كفر سليم (sec. 2, } \\
\text { part 1, p. 60) }\end{array}$ & $\begin{array}{l}\text { 1- the /a/ of Sali:m is dropped, } \\
\text { rendering an initial CC. } \\
2-/ \partial / \text { is used for juncture }\end{array}$ & $\begin{array}{l}\text { /kāfr-ə-sli:m/ } \\
\text { كفر سليم (It is named after its founder Sheikh } \\
\text { seli:m Pel-Marsafey, one of Al-Azhar } \\
\text { scholars.) }\end{array}$ \\
\hline $\begin{array}{l}\text { /kāfr muhammad } \\
\text { g(3)a:wi:fl } \quad \text { مفمد جاويش (sec. } \\
\text { 2, part } 1, p, 95)\end{array}$ & $\begin{array}{l}1-/ \mathrm{g} / \text { or } / 3 / \text { is substituted by a } \\
/ \mathrm{J} / \text { to match the final } / \mathrm{J} / \\
\text { (regressive assimilation). } \\
\text { 2-/a/ is added for juncture } \\
3-/ \mathrm{u} / \text { is elided rendering an } \\
\text { intial CC (mh). }\end{array}$ & $\begin{array}{l}\text { /kāfr-ə-mhammad Jawi:J/ كفر محمد شاويش } \\
\text { Because people used to pronounce it as } \\
\text { /kāfr mohammad Ja:wi:f/ instead of } \\
\mathrm{g}(3) \mathrm{a} \text { :wi: } \int \text {, the name changed in order to } \\
\text { reach a harmony between writing and } \\
\text { pronunciation (Ramzy, 1994). }\end{array}$ \\
\hline $\begin{array}{l}\text { /kāfr Jārāf- } \\
\text { uddi:n/ كرفر شرف الدين (sec. 2, part } \\
\text { 1, p. 23) }\end{array}$ & $\begin{array}{l}\text { 1-The SA /u/ of Jārāf- } \\
\text { uddi:n is replaced by an /i/ in } \\
\text { EA pronunciation. } \\
\text { 2-/ə/ is added for juncture. }\end{array}$ & $\begin{array}{l}\text { /kāfr-ə-Jārāf-i-ddi:n/ كفر شرف الدين (masc. } \\
\text { proper noun) }\end{array}$ \\
\hline 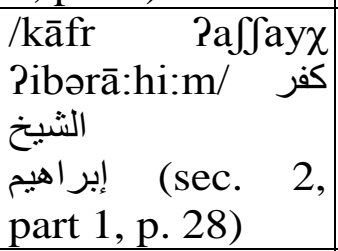 & $\begin{array}{l}1-\text { The sequence /ay/ is } \\
\text { replaced by /ee/ in EA. } \\
2-/ \partial / \text { is added for juncture } \\
3-/ \partial / \text { is elided in Ibrahim and } \\
\text { the /â:/ is shortened in EA. }\end{array}$ & 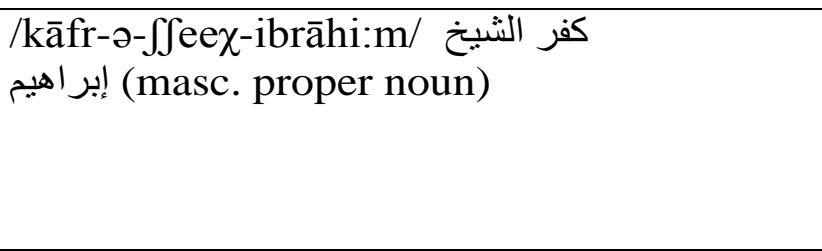 \\
\hline 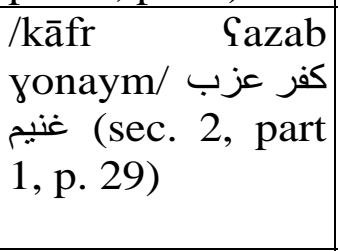 & $\begin{array}{l}\text { 1-The /ay/ of yonaym is } \\
\text { replaced by /ee/ in EA. } \\
\text { 2-/a/ is added for juncture } \\
\text { 3- Some dialects render it as / } \\
\text { yneem/ eliding the /o/ }\end{array}$ & 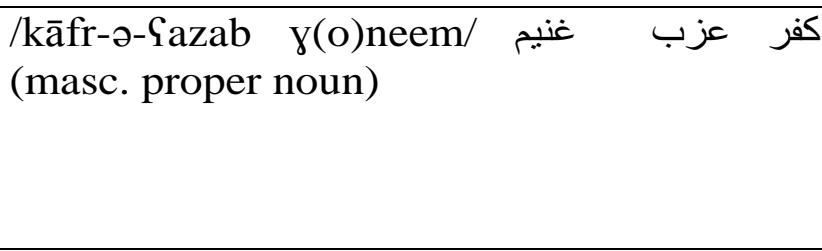 \\
\hline $\begin{array}{l}\text { /kāfr muways/ } \\
\text { كفر مويس (sec. 2, } \\
\text { part 1, p. 30) }\end{array}$ & $\begin{array}{l}\text { 1- The /u/ of muways is } \\
\text { dropped and the diphthong/ay/ } \\
\text { is replaced by /ee/ in EA. } \\
\text { 2- /a/ is added for juncture. } \\
3-\text { The } / \mathrm{m} / \text { is geminated. }\end{array}$ & $\begin{array}{l}\text { /kāfr-ə-mmwees/ كفر مويس (1994), the word } \\
\text { According to Ramzy } \\
\text { muways is the diminutive form of Mousa. } \\
\text { /mo/ means water in Egyptian and /sa/ son } \\
\text { (Elhadary, 2016). }\end{array}$ \\
\hline $\begin{array}{l}\text { /kāfr } \quad \text { Pal-Sarāb/ } \\
\text { كفر العرب (sec. 2, } \\
\text { part 1, p. 29) }\end{array}$ & $\begin{array}{l}1-\text { The } / \mathrm{P} / \text { of the definite } \\
\text { article is deleted and the } / \mathrm{a} / \text { is } \\
\text { replaced by a } / \mathrm{a} / \text {. } \\
\text { 2- An } / \overline{\mathrm{a}} / \text { replaces the SA } / \mathrm{a} / \text {. }\end{array}$ & /kāfr-ə-1Cāāāb/كفر العرب (Origin unknown) \\
\hline $\begin{array}{l}\text { /kāfr SaSd/ كفر (sec. 2, part } \\
\text { سعد (, p. 29) }\end{array}$ & $/ \mathrm{a} /$ is added for juncture. & /kāfr-ə-SaSd/ كفر سعد (masc.proper noun) \\
\hline 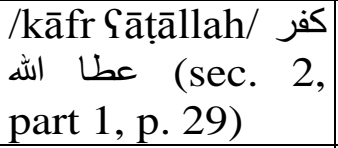 & $/ \partial /$ is added for juncture. & $\begin{array}{l}\text { /kāfr-ə-Yāțāllah/ كفر عطا الله (masc. proper } \\
\text { noun) }\end{array}$ \\
\hline /kāfr mansu:r/ & $1-/ \partial /$ is added for & /kāfr-ə-mānșu:r/ كفر منصور (masc. proper \\
\hline
\end{tabular}


كفر منصور (sec. 2, juncture.

part 1, p. 30)

juncture.
probably is replaced by an $/ \bar{a} /$
/s/

noun)

\subsubsection{Compound place names with /bani/:}

Table (5) includes compound place names that all contain the word /bani/ "sons of...". The word /bani/ indicates that this place name is possibly derived from the offspring of a person/tribe ( 7 out of 10 are also masc. sing proper nouns). These names are all genitive constructions. Thus, these names can be schematized as follows:

\begin{tabular}{|c|c|c|}
\hline \multicolumn{3}{|c|}{ Table (5) } \\
\hline $\begin{array}{l}\text { Original Forms } \\
\text { represented } r \text { by } \\
\text { Ramzy and page } \\
\text { numbers }\end{array}$ & Morpho-phonological Changes & Current EA Form \\
\hline $\begin{array}{l}\text { /bani murr/ بنى مر } \\
\text { (sec. 2, part 4, p. } \\
11 \text { ) }\end{array}$ & The /u/ is replaced by /o/ in EA. & بنى مر /bani morr/ بن \\
\hline $\begin{array}{l}\text { /banimag(3)du:1/ } \\
\text { part 3, p. 59) }\end{array}$ & $\begin{array}{l}\text { Using /g/ or } / 3 / \text { depends on the } \\
\text { dialect }\end{array}$ & /bani mag(3)du:1/ بنى مجدول \\
\hline 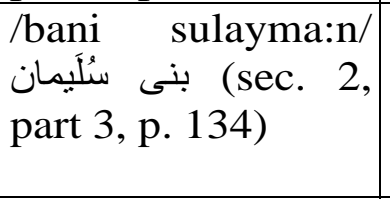 & $\begin{array}{l}1-\text { The } / \mathrm{u} / \text { is elided and the } / \mathrm{s} / \text { is } \\
\text { geminated in EA. } \\
2-\text { The diphthong /ay/ is replaced } \\
\text { by /i/. }\end{array}$ & /bani-s- slima:n/بنى سِليمان \\
\hline $\begin{array}{l}\text { /bani yunaym/ بنى ( غنيم (sec. 2, part 3, } \\
\text { p. 134) }\end{array}$ & $\begin{array}{l}1-\text { The /ay/ is replaced by /ee/ in } \\
\mathrm{EA} \text {, and the } / \mathrm{u} / \text { is replaced by } / \mathrm{o} / \text {. } \\
2-/ \mathrm{O} / \text { is deleted in some dialects. }\end{array}$ & بنى غنيم/bani y(o)neem \\
\hline $\begin{array}{l}\text { /bani nusāyr/ نصى (sec. 2, part 3, } \\
\text { p. 134) }\end{array}$ & $\begin{array}{l}\text { 1- The } / u / \text { is replaced by } / \mathrm{o} / \text {. } \\
2-\text { The sequence/āy/ is replaced by } \\
\text { /ee/ in EA. } \\
3-\text { The /o/ is deleted in some } \\
\text { dialects. }\end{array}$ & بنى نصير/bani n(o)Seer/ \\
\hline $\begin{array}{l}\text { /bani qā:sem/ بنى } 1 \text { (sec. 2, part 3, } \\
\text { p. 137) }\end{array}$ & $\begin{array}{l}\text { 1- The /q/ is replaced either by an } \\
/ 2 / \text { or a } / \mathrm{g} / \text { according to the area. } \\
2 \text { - the } / \overline{\mathrm{a}}: / \text { is replaced by an } / \mathrm{a}: / \text {, due } \\
\text { to the substitution of the emphatic } \\
\text { /q/. }\end{array}$ & بنى اسم- جاسم/bani P(g)a:sem \\
\hline $\begin{array}{l}\text { /bani } \chi \text { بali:1/ بنى خليل } \\
\text { (sec. 2, part 3, p. } \\
\text { 145) }\end{array}$ & --------------------- & 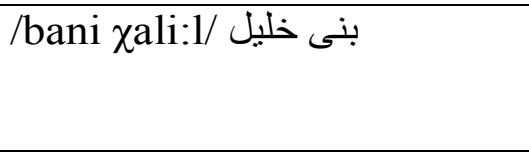 \\
\hline $\begin{array}{l}\text { /bani Sawāḍ/ بنى } \\
\text { عوض (sec. 2, part } \\
\text { 3, p. 145) }\end{array}$ & The /a/ is replaced by an $/ \bar{a} /$ in EA. & بنى عوض /bani Sāwāḍ / \\
\hline $\begin{array}{l}\text { /bani ha:ru:n/ بنى هارون(sec. 2, part 3, } \\
\text { p. 157) }\end{array}$ & The /a:/ is replaced by a short /ā/. & /bani hāru:n/بنى هارون \\
\hline
\end{tabular}




\begin{tabular}{|c|c|c|}
\hline 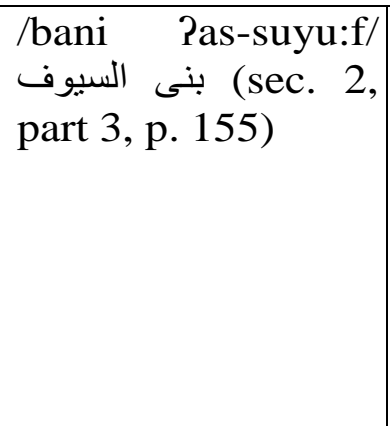 & $\begin{array}{l}\text { /bani Pas-suyu:f/ > /bani suwayf/ > } \\
\text { /bani-s-sweef/ } \\
\text { The word "suyu:f" in Arabic means } \\
\text { "swords". The original form is } \\
\text { taken from a battle in which people } \\
\text { used swords. } \\
\text { 1- The /s/ is geminated. } \\
\text { 2- The /ay/ is replaced by an /ee/ } \\
\text { and/u/is elided. }\end{array}$ & بنى سويف /bani-s-sweef/ \\
\hline
\end{tabular}

\begin{tabular}{|c|c|c|}
\hline \multicolumn{3}{|c|}{ Table (6) } \\
\hline $\begin{array}{c}\text { Original Forms } \\
\text { represented by } \\
\text { Ramzy and page } \\
\text { numbers }\end{array}$ & $\begin{array}{c}\text { Morpho-phonological } \\
\text { Changes }\end{array}$ & Current EA Form and meaning \\
\hline $\begin{array}{l}\text { /nazlat } \\
\text { Passamma:n/ نزلة السَّمَان (sec. 2, part } \\
\text { 3, p. 24) }\end{array}$ & $\begin{array}{l}\text { 1-The second /a/ of nazlat is } \\
\text { replaced by an /e/ in EA. } \\
\text { 2- The /ə/ is added for } \\
\text { juncture. } \\
\text { 4- The } / 2 / \text { is elided. } \\
5-\text { The } / a / \text { is replaced by } / \mathrm{i} / \text {. }\end{array}$ & $\begin{array}{l}\text { /nazlet-ə-ssimma:n/ نزلة السِمّان "quail" in } \\
\text { /Simma:n/ means "quale } \\
\text { Arabic. (Unknown origin) }\end{array}$ \\
\hline $\begin{array}{l}\text { /nazlat bafi:r/ نَشيرلة(sec. 2, part 3, } \\
\text { p. 107) }\end{array}$ & $\begin{array}{l}\text { The /a/ of bafi:r is replaced } \\
\text { by an /e/ in EA, which is } \\
\text { elided in some dialects. }\end{array}$ & 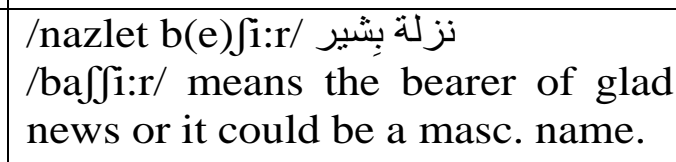 \\
\hline $\begin{array}{l}\text { /nazlat } \\
\text { g(3)unaydi/ } \quad \text { (sec. } \\
\text { 2, part 3, p. 135) }\end{array}$ & $\begin{array}{l}\text { 1- The /l/ is assimilated into } \\
/ \mathrm{g} / \text { or } / 3 / \text { according to the } \\
\text { area it is used } \mathrm{in}(/ \mathrm{g} / \text { is solar } \\
\text { in EA.) } \\
2-\text { The } / \mathrm{u} / \text { is replaced by an } \\
\text { /e/. } \\
\text { 3- The /ay/ is replaced by } \\
\text { /ee/. }\end{array}$ & $\begin{array}{l}\text { نزلة الجنيدى /nazlet-2-gg(33)eneedi) } \\
\text { (Unknown origin) }\end{array}$ \\
\hline $\begin{array}{l}\text { /nazlat Pad-di:b/ } \\
\text { نزلة (section } \\
\text { 2, part 3, p. 149) }\end{array}$ & $\begin{array}{l}\text { 1-The /l/ of the definite } \\
\text { article is assimilated into /d/ } \\
2-\text { A weak /a/ is inserted in } \\
\text { the juncture to connect the } \\
\text { parts of the construction. }\end{array}$ & $\begin{array}{l}\text { /nazlet-ə-ddi:b/ نزلة الديب } \\
\text { The word /di:b/ means "wolf" in } \\
\text { EA and it is used as a family } \\
\text { name. }\end{array}$ \\
\hline 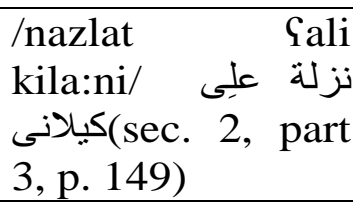 & $\begin{array}{l}\text { /Kila:ni/ > /k(i)lani/ } \\
\text { The /i/ of /kila:ni/ is deleted } \\
\text { in some dialects and the /a:/ } \\
\text { is shortened. }\end{array}$ & $\begin{array}{l}\text { نزلة على كيلانى } 1 \text { /nazlet Gali } \\
\text { Both forms } \\
\text { ki:lani/klani/ are used. (Unknown } \\
\text { origin) }\end{array}$ \\
\hline $\begin{array}{l}\text { /nazlat نزلة } \\
\text { mama:li:k/ المماليك (sec. 2, part } \\
\text { 3, p. 169) }\end{array}$ & $\begin{array}{l}\text { 1- The } / \mathrm{T} / \text { is deleted. } \\
2-\mathrm{A} / \mathrm{/} / \text { is inserted as a } \\
\text { linking vowel and the /a:/ is } \\
\text { shortened. }\end{array}$ & $\begin{array}{l}\text { /nazlet-o-lmamali:k/ نزلة المماليك } \\
\text { (mama:li:k is the plural of } \\
\text { mamlu:k) }\end{array}$ \\
\hline
\end{tabular}




\begin{tabular}{|c|c|c|}
\hline $\begin{array}{l}\text { /nazlat } \quad \text { saSd } \\
\text { g(3)a:wi:J/ جزلة سعد(sec. 2, part } \\
\text { 3, p. 169) }\end{array}$ & $\begin{array}{l}\text { /nazlat saSd g(3)a:wi:Jl > } \\
\text { /nazlet Jawi:J/ } \\
\text { For facilitation, the } \\
\text { masc.proper noun /saSd/ was } \\
\text { dropped and as mentioned } \\
\text { before the word /g(3)a:wi: } / \\
\text { is pronounced as /Jawi:J/. } \\
\text { This involves a consonant } \\
\text { change (assimilation) and a } \\
\text { vowel shortening into /a/. }\end{array}$ & $\begin{array}{l}\text { /nazlet Jawi:f/ } \\
\text { (Unknown origin) }\end{array}$ \\
\hline $\begin{array}{l}\text { /nazlat Jari:f/ نزلة شريف (sec. 2, part } \\
\text { 3, p. 170) }\end{array}$ & $\begin{array}{l}\text { The /a/ of /shari:f/ is replaced } \\
\text { by an /e/ in EA, which is } \\
\text { elided in some dialects. }\end{array}$ & $\begin{array}{l}\text { /nazlet } \int(\mathrm{e}) \text { ri:f/ نزلة شريف } \\
\text { It is named after Mohammed } \\
\text { Sherif Pasha, one of the ex-prime } \\
\text { ministers in Egypt. }\end{array}$ \\
\hline $\begin{array}{l}\text { /nazlat maSa:rik/ } \\
\text { نزلة كَعَارك (sec. 2, } \\
\text { part 3, p. 170) }\end{array}$ & $\begin{array}{l}\text { The /a/ of nazlat and final the } \\
\text { /i/ of maSa:rik are replaced } \\
\text { by two /e/ sounds in EA. }\end{array}$ & $\begin{array}{l}\text { /nazlet maSa:rek/ } \\
\text { It is named after Sheikh Tohaami } \\
\text { bek MaSa:rik Sazzu:z, the owner of } \\
\text { one of the districts in this area. }\end{array}$ \\
\hline 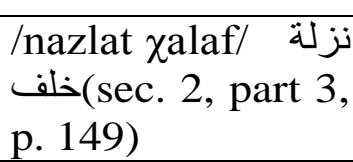 & \multirow[t]{3}{*}{$\begin{array}{l}\text { Only the second } \mathrm{V} / \mathrm{a} / \text { of } \\
\text { nazlah is replaced by /e/ in } \\
\text { EA. }\end{array}$} & $\begin{array}{l}\text { /nazlet xalaf/ نزلة خلف (Unknown } \\
\text { origin) }\end{array}$ \\
\hline $\begin{array}{l}\text { /nazlat saSi:d/ نزلة سعيد (sec. 2, part } \\
\text { 3,p. 149) }\end{array}$ & & $\begin{array}{l}\text { /nazlet saSi:d/ نزلة سعيد(Unknown } \\
\text { origin) }\end{array}$ \\
\hline $\begin{array}{l}\text { /nazlat ramāḍā:n/ } \\
\text { pزلة رمضان (sec. 2, } \\
\text { part 3, p. 256) }\end{array}$ & & $\begin{array}{l}\text { /nazlet rāmāọā:n/ } \\
\text { It is named after Sheikh Ramaḍā:n } \\
\text { Sabd Rabbuh, one of the most } \\
\text { outstanding farmers in this } \\
\text { area.Hence, the name has an } \\
\text { originally EA origin, yet Ramadan } \\
\text { is originally SA word. }\end{array}$ \\
\hline
\end{tabular}

\section{[[bani(u)] [X]N.] Genitive Construction $\leftrightarrow$ The sons of $X$.}

\subsubsection{Compounds which include nazlet(nazlat/h):}

The following place names contain the word /nazlah(t)/, whose origin

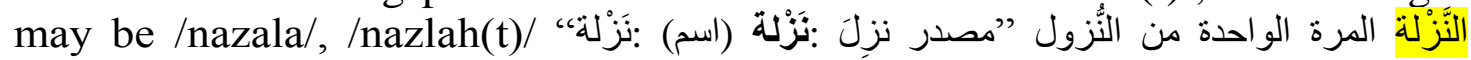
(Baheth: Lisa:n Pal-Yarāb), which means descended/arrived in an area only once. This word ends in /ta:? marbu:țah/ that is pronounced as /t/ when followed by another word in EA, but is converted to $/ \mathrm{h} /$ before silence. It is pronounced as /nazlet/ in EA. A following weak /ə/ is sometimes inserted for juncture after /nazlet/. The following place names are also genitive constructions that are formed through compounding, with a majority of masc. sing names also (10 out of 12). They can be represented by the following schema: 


\subsubsection{Compounds with / $\operatorname{Sezbeh}(\mathbf{t}) /$ :}

The following table includes compound place names, which start with the word /Sizbah/ (farm). It is believed to have originated from /

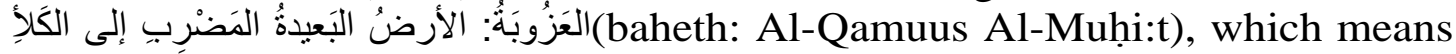
the far land sought by people for its pasture. In EA, the /a/ was changed to /e/ and $/ \mathrm{u}$ :/ was elided rendering medial CC. It may have been changed initially to / $i$ izbah(t)/, changing /a/ to / $\mathrm{i} /$, then the previous changes were effected. However, According to Ramzy (1994), the word / Sizbah/ denotes a territory that exceeds 50 fidans and owned by one person or a family. This land is always used for agriculture and farming for the benefit of its owner (sec. $1 \mathrm{p}$. 5), which may denote that it underwent a slight semantic shift. The genitive constructions with / /izbah/ have predominantly masc. sing proper nouns (13 out of 15). In some cases, /o/ or / $/$ / is inserted for juncture. They can be represented by the following schema:

[Sezbet [X]N.] Genitive Construction $\leftrightarrow$ The Farm of X.

\begin{tabular}{|c|c|c|}
\hline \multicolumn{3}{|c|}{ Table (7) } \\
\hline $\begin{array}{c}\text { Original Form } \\
\text { represented by } \\
\text { Ramzy and page } \\
\text { numbers }\end{array}$ & $\begin{array}{c}\text { Morpho-phonological } \\
\text { Changes }\end{array}$ & $\begin{array}{c}\text { Current Form and } \\
\text { meaning }\end{array}$ \\
\hline $\begin{array}{l}\text { /Gizbat Pal-burg(3)/ } \\
\text { عزبة البرج } \\
\text { (sec. 2, part 1,p. } \\
\text { 249) }\end{array}$ & $\begin{array}{l}\text { 1- The } / \mathrm{u} / \text { is replaced by } \\
\text { an } / \mathrm{o} / \text { in EA. } \\
\text { 2- The final consonant is } \\
\text { either pronounced as a } / \mathrm{g} / \\
\text { or } / 3 / \text { according to the } \\
\text { area. } \\
3 \text { - An } / \partial / \text { is added for } \\
\text { juncture. }\end{array}$ & 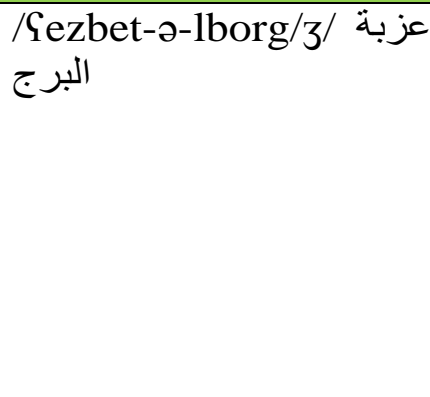 \\
\hline 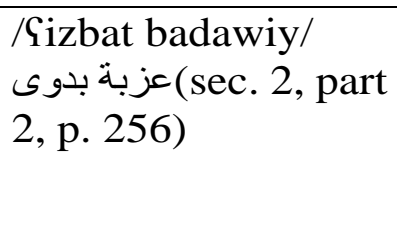 & The final /y/ is elided. & $\begin{array}{l}\text { / عزبة / عezbet badawi } \\
\text { This place is called after } \\
\text { its founder, Mohamed } \\
\text { bek Badawi. }\end{array}$ \\
\hline $\begin{array}{l}\text { / Sizbat Sāmr/ عزبة (sec. 2, part 2, } \\
\text { pمرو 118) }\end{array}$ & ------------ & $\begin{array}{l}\text { عزبة عمرو/Sezbet ؟āmr } \\
\text { (masc. proper name) }\end{array}$ \\
\hline $\begin{array}{l}\text { /Gizbat Pabu-zurayq/ } \\
\text { عزبة أبوزريق } \\
\text { (sec. 2, part 2,p. } \\
\text { 256) }\end{array}$ & $\begin{array}{l}\text { 1- The /u/ of /zurayq/ is } \\
\text { dropped forming a CC, } \\
\text { and the diphthong/ay/ is } \\
\text { replaced by /ee/. } \\
\text { 2- The /q/ is replaced } \\
\text { either by a glottal stop /?/ } \\
\text { or a /g/ according to the }\end{array}$ & $\begin{array}{l}\text { /Yezbet Pabu- } \\
\text { zزبة أبوزريئ(g)eP(g) }\end{array}$ \\
\hline
\end{tabular}




\begin{tabular}{|c|c|c|}
\hline & area. & \\
\hline 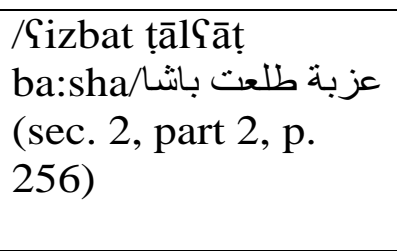 & ------------------------ & $\begin{array}{l}\text { / عزبة طلعت باشَ/ عezbet tāāt } \\
\text { ba:sha/could be formed } \\
\text { (could } \\
\text { originally as an EA } \\
\text { name) }\end{array}$ \\
\hline $\begin{array}{l}\text { /Gizbat yu:suf } \\
\text { PalGaskariy/ عزبة العسكرى (sec. 2, } \\
\text { part 2, p. 256) }\end{array}$ & $\begin{array}{l}\text { 1-The final /u/ of yu:suf } \\
\text { is replaced by an/i/. } \\
\text { 2- An /i/ is inserted for } \\
\text { juncture instead of } / \mathrm{R} / \text {. } \\
3-/ y / \text { is elided }\end{array}$ & $\begin{array}{l}\text { /Cezbet yu:sif-i-1- } \\
\text { Saskari/ عزبة يوسفى العسكرى }\end{array}$ \\
\hline $\begin{array}{l}\text { /Yizbat Pas- } \\
\text { salankiy/عزبة السلانكى } \\
\text { (sec. 2, part 2,p. } \\
\text { 294) }\end{array}$ & $\begin{array}{l}\text { 1- The } / \mathrm{P} / \text { is elided. } \\
\text { 2- /i/ is added for } \\
\text { juncture. } \\
3 \text { - The final / } / \text { / is elided. }\end{array}$ & 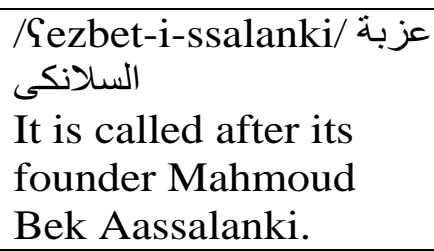 \\
\hline $\begin{array}{l}\text { /Gizbat muhammad } \\
\text { hنlmi/ عزبة محمد حلمى } \\
\text { (sec. 2, part 2,p. } \\
\text { 295) }\end{array}$ & \multirow{2}{*}{$\begin{array}{l}\text { The /u/ sound of } \\
\text { Mohamed is replaced by } \\
\text { a weak /ə/ in EA, or } \\
\text { dropped altogether in the } \\
\text { two instances of } \\
\text { Mohamed. } \\
\text { 1- The word Afandi is } \\
\text { dropped. } \\
\text { 2- The /a/ of Sawād is } \\
\text { replaced by /ā/ probably } \\
\text { under influenceof its } \\
\text { environment /ā/ and /d̂ } \\
\text { (regressive assimilation) }\end{array}$} & $\begin{array}{l}\text { /Gezbet m(ə)hammad } \\
\text { hزبة محمد حلمى/mimi }\end{array}$ \\
\hline $\begin{array}{l}\text { /Sizbat Muhạammad } \\
\text { Afandi Sawāḍ عزبة عمد أفندى عوض (sec. } \\
\text { 2, part 2, p. 295) }\end{array}$ & & $\begin{array}{l}\text { / عزبة محمد عوض/Sezbet məhammad } \\
\text { ؟āwāḍ// }\end{array}$ \\
\hline 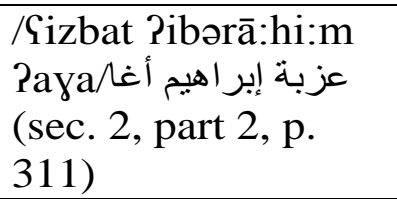 & $\begin{array}{l}\text { The schwa is elided and } \\
\text { vowel /ā:/ is shortened in } \\
\text { EA. }\end{array}$ & $\begin{array}{l}\text { /Cezbet Pibrāhi:m } \\
\text { Pزبة إبراهيم أغا/Payaara }\end{array}$ \\
\hline $\begin{array}{l}\text { /Gizbat mustāafa Pal- } \\
\text { 3ama:firgiy/ عزبة الجماثرجى (sec. 2, } \\
\text { part 2,p. 312) }\end{array}$ & $\begin{array}{l}\text { 1- The } / 1 / \text { is assimilated } \\
\text { into the / } / \text { / in EA. } \\
2 \text { - the } / 3 / \text { is replaced by a } \\
\text { / } / \text { (regressive } \\
\text { assimilation probably for } \\
\text { ease of articulation). } \\
\text { 3- The /a:/ is shortened. } \\
\text { 4- the final /y/ is elided. }\end{array}$ & $\begin{array}{l}\text { /Sezbet-i- } \\
\text { عزبة / الثمشرجى }\end{array}$ \\
\hline 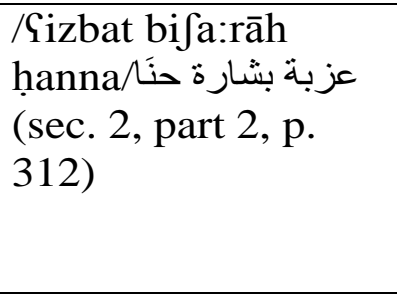 & $\begin{array}{l}\text { 1- The /i/ of bifa:rāh is } \\
\text { replaced by an /e/. } \\
\text { 2- the/a:/ is replaced by } \\
\text { an /ā:/ in EA under } \\
\text { influence from emphatic } \\
\text { /r/. }\end{array}$ & 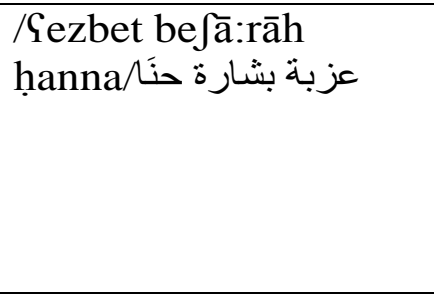 \\
\hline $\begin{array}{l}/ \text { عizbat sāqr/ صزبة صقر (sec. 2, part 2, } \\
\text { p. 313) }\end{array}$ & $\begin{array}{l}\text { The /q/ is replaced either } \\
\text { by a /g/ or an / } / \text { in EA. }\end{array}$ & $\begin{array}{l}\text { عزبة / عezbet șāP(g)r/ صقر } \\
\text { The word /sāqr/ means }\end{array}$ \\
\hline
\end{tabular}




\begin{tabular}{|c|c|c|}
\hline & & falcon in Arabic. \\
\hline $\begin{array}{l}\text { عزبة / عزية } 2 \text { (sec. 2, part 2, } \\
\text { p. 314) }\end{array}$ & \multirow{2}{*}{$\begin{array}{l}\text { The /q/ is replaced either } \\
\text { by an / / or a /g/ in EA. } \\
\text { /u/> /o/ } \\
\text { The proper noun / } 2 \bar{r} r t i: n / \\
\text { is dropped in The current } \\
\text { form. }\end{array}$} & $\begin{array}{l}\text { عزبة/Gezbet mor?(g)os مرقص } \\
\text { مرقد }\end{array}$ \\
\hline 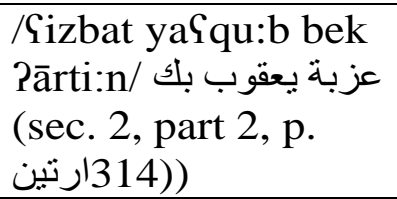 & & 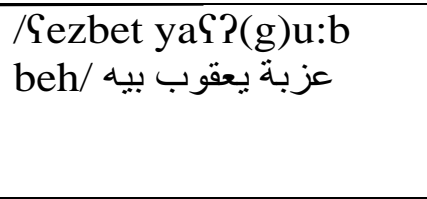 \\
\hline
\end{tabular}

\subsubsection{Compounds which include/Pabu/:}

The following table contains place names which start with the word 'Pabu' (the father of ...). These are genitive constructions, also with a majority of masc. sing proper nouns: 10 out of 13. The following morphological schema can represent these constructions:

[?abu [X]N.] Genitive Construction

\begin{tabular}{|c|c|}
\hline \multicolumn{2}{|r|}{ Table (8) } \\
\hline $\begin{array}{l}\text { Current EA Forms represented } \\
\text { by Ramzy and page numbers }\end{array}$ & $\begin{array}{c}\text { Meaning or Reason for Naming } \\
\text { and changes }\end{array}$ \\
\hline $\begin{array}{l}\text { /Pabu-ḥamma:d/ أبو حماد (sec. 2, } \\
\text { part 1,p. 65) }\end{array}$ & $\begin{array}{l}\text { This place was originally called } \\
\text { "banub" (Coptic) and then this name } \\
\text { disappeared and the current form is } \\
\text { derived from the name of Sheikh } \\
\text { Ahmed Abu-Hamma:d who is } \\
\text { buried there. }\end{array}$ \\
\hline $\begin{array}{l}\text { /Pabu-mā:ḍi/أبو ماضى (sec. 2, part } \\
\text { 2,p. 29) }\end{array}$ & $\begin{array}{l}\text { It is called after Sheikh Mohamed } \\
\text { Abu-Madi who is buried there. }\end{array}$ \\
\hline $\begin{array}{l}\text { /Rabu-yani:mah/أبو غنيمة/ (sec. 2, } \\
\text { part 2, p. 51) }\end{array}$ & $\begin{array}{l}\text { This place was founded by ha33 } \\
\text { Mohamed Yu:sef Abu-yani:mah and } \\
\text { called after him. }\end{array}$ \\
\hline $\begin{array}{l}\text { /Pabu-nnaga/ أبو النجا (sec. 2, part } \\
\text { 2, p. 39) }\end{array}$ & Unknown origin \\
\hline $\begin{array}{l}\text { /Pabu-tama:dah/أبو تمادة (sec. 2, } \\
\text { part 2,p. 39) }\end{array}$ & Unknown origin \\
\hline $\begin{array}{l}\text { /Rabu-Yawa:li/أبو عو الى (sec. 2, part } \\
\text { 2, p. 167) }\end{array}$ & After sheikh Abu-Cawaali \\
\hline $\begin{array}{l}\text { /Rabu-sneețah/أبو سنيطة (section 2, } \\
\text { part 2,p. 213) }\end{array}$ & $\begin{array}{l}\text { The origin of the noun may be } \\
\text { /Pabu-sunāytāh/. Therefore, the /u/ is } \\
\text { dropped and the /āy/ is replaced by } \\
\text { /ee/. }\end{array}$ \\
\hline $\begin{array}{l}\text { أبو المطامير/Rabu-1-mātāāmi:rart 2, p. 232) } \\
\text { (section 2, part }\end{array}$ & $\begin{array}{l}\text { /Pal-mātāmi:r/is the plural of / Pal- } \\
\text { mațu:rah/ which means a storage } \\
\text { for grains (baheth). Thus, the /a/ is } \\
\text { replaced by an } / \bar{a} / \text { in EA. }\end{array}$ \\
\hline
\end{tabular}




\begin{tabular}{|c|c|}
\hline $\begin{array}{l}\text { أبو حمص/Rabu-hommosomion (section } \\
\text { 2, part 2, p. 237) }\end{array}$ & Unknown origin \\
\hline $\begin{array}{l}\text { /Rabu-masSu:d/ أبو مسعود (section } \\
\text { 2, part 2, p. 263) }\end{array}$ & $\begin{array}{l}\text { This place was called /Pāttlāmi:s } \\
\text { Passuyra/ ألميس الصغرى but was } \\
\text { famous for this current name. Thus, } \\
\text { the old one disappeared. }\end{array}$ \\
\hline $\begin{array}{l}\text { /Pabu-maJhu:r/أبو مشهور (sec. 2, } \\
\text { part 2,p. 3) }\end{array}$ & $\begin{array}{l}\text { This place is called after Sheikh Ali } \\
\text { Abu-Mashhuur who is buried there. }\end{array}$ \\
\hline $\begin{array}{l}\text { /Pabu-qi:r/ أبو قير pronounced as } \\
\text { /Pabu-?(g)i:r/ according to the } \\
\text { area. } \\
\text { (section } 2 \text {, part } 2, \text { p. } 317 \text { ) }\end{array}$ & $\begin{array}{l}\text { According to Ramzy (1994), this } \\
\text { place is named after "Saint Cyr" } \\
\text { القديس قير, one of the martyrs who } \\
\text { struggled to spread Christianity in } \\
\text { Egypt and was known as "Apakir or } \\
\text { Abbakyr". }\end{array}$ \\
\hline
\end{tabular}

\subsubsection{Compounds which include genitive constructions with /ko:m/:}

The place names in the following table all start with the Egyptian Arabic word, originally Arabic كوم/kawm/ (pile) followed by a noun. In EA, the diphthong /aw/ is often replaced by the long vowel /o:/. Like the other names presented above, a weak / / / is sometimes added for juncture as a linking vowel. The nouns can be either definite or indefinite. Thus, the following schema can represent them:

[ko:m [X] def. (indef.)N.] Genitive Construction $\leftrightarrow$ The Pile of X

\begin{tabular}{|c|c|c|}
\hline \multicolumn{3}{|c|}{ Table (9) } \\
\hline $\begin{array}{l}\text { Original Forms } \\
\text { represented by Ramzy } \\
\text { and page numbers }\end{array}$ & $\begin{array}{c}\text { Morpho-phonological } \\
\text { Changes }\end{array}$ & EA Form and meaning \\
\hline $\begin{array}{l}\text { /kawm Sas-samn/ } \\
\text { كوم السمن (section 2, part } \\
\text { 1, p. 37) }\end{array}$ & $\begin{array}{l}\text { The } / \mathrm{R} / \text { is dropped and the } \\
\text { /a/ is replaced by an /o/ } \\
\text { inserted for juncture. }\end{array}$ & $\begin{array}{l}\text { /ko:m-ə-ssamn/ } \\
\text { كوم السمن (Unknown origin) }\end{array}$ \\
\hline $\begin{array}{l}\text { /kawm Pal-Pātru:n/ } \\
\text { كوم الأطرون (sec. 2, part } \\
\text { 1, p. 47) }\end{array}$ & $\begin{array}{l}\text { 1- The } / 2 / \text { is dropped and } \\
\text { a /a/ is inserted. }\end{array}$ & $\begin{array}{l}\text { /ko:m-ə-lPāṭu:n/ } \\
\text { كوم الأطرون (Unknown origin) }\end{array}$ \\
\hline $\begin{array}{l}\text { كوم إجفين /kawm Pizfi:n/ } \\
\text { (sec. 2, } \\
\text { part 1, p. 58) }\end{array}$ & $\begin{array}{l}\text { 1-The } / 3 / \text { is replaced by a } \\
\text { voiceless } / \mathrm{f} / \text { to match the } \\
\text { following voiceless } \\
\text { fricative /f/ and the /i/ is } \\
\text { replaced by an /a/. } \\
2-\text { In EA pronunciation, } \\
\text { the } / \mathrm{T} / \text { is often dropped. }\end{array}$ & $\begin{array}{l}\text { /ko:m-affi:n/ } \\
\text { (Unknown origin) }\end{array}$ \\
\hline $\begin{array}{l}\text { /kawm Sal-Pafrā:f/ } \\
\text { كوم الأشر اف (sec. 2, part } \\
\text { 2, p. 259) }\end{array}$ & $\begin{array}{l}\text { 1-The } / \mathrm{R} / \text { is dropped and a } \\
\text { weak / / is used. } \\
2 \text { - The /a/ of / } \mathrm{Pa} \int \mathrm{ra}: \mathrm{f} / \text { is } \\
\text { replaced by an } / \overline{\mathrm{a}} / \text { in EA } \\
\text { under the influence of } / \mathrm{r} / \text {. }\end{array}$ & $\begin{array}{l}\text { /ko:m-2-lPājrā:f/ } \\
\text { كوم الأشر اف (the word Pa Jrā:f) } \\
\text { means honored in Arabic, or the } \\
\text { noble clan of the holy prophet } \\
\text { (Unknown origin) }\end{array}$ \\
\hline /kawm & A /l/ is dropped and the & /ko:mSali/ \\
\hline
\end{tabular}




\begin{tabular}{|c|c|c|}
\hline $\begin{array}{l}\text { كوم على (sec. 2, part 2, } \\
\text { p. 106) }\end{array}$ & $\begin{array}{l}\text { final /yy/ are dropped in } \\
\text { EA. }\end{array}$ & $\begin{array}{l}\text { - masc.name (Unknown } \\
\text { origin) }\end{array}$ \\
\hline $\begin{array}{l}\text { /kawm Sayya:d/ } \\
\text { كوم عياد (sec. 2, part 2, } \\
\text { p. 170) }\end{array}$ & & $\begin{array}{l}\text { /ko:m } \\
\text { Sayya:d/ } \\
\text { كوم(Unknown origin) }\end{array}$ \\
\hline $\begin{array}{l}\text { /kawm كوم مازن (sec. 2, part 2, } \\
\text { p. 183) }\end{array}$ & $\begin{array}{l}\text { The /i/ of ma:zin is } \\
\text { replaced by an /e/ in EA. }\end{array}$ & $\begin{array}{l}\text { /ko:m ma:zen/ } \\
\text { كوم مازن (Unknown origin) }\end{array}$ \\
\hline $\begin{array}{l}\text { /kawm?aḍ-ḍabS/ } \\
\text { كوم الضبع (section 2, part } \\
\text { 2, p. 222) }\end{array}$ & $\begin{array}{l}\text { 1-The /P/ of the definite } \\
\text { article is elided. } \\
2-\text { a / / is inserted for } \\
\text { juncture. }\end{array}$ & $\begin{array}{l}\text { /ko:m-ə-ḍ̂ābS/ } \\
\text { كوم الضبع (Jnknown origin) } \\
\text { The word /ḍābS/ means "hyaena" } \\
\text { in Arabic. }\end{array}$ \\
\hline $\begin{array}{l}\text { /kawmPal-bāsāl/ } \\
\text { كوم البصل (sec. 2, part 2, } \\
\text { p. 242) }\end{array}$ & & $\begin{array}{l}\text { /ko:m-ə-lbāsāl/ } \\
\text { كوم البصل (Unknown origin) } \\
\text { /bāșāl/ means "onion". }\end{array}$ \\
\hline $\begin{array}{l}\text { /kawmpal- } \\
\text { hanafl } \\
\text { كوم (section } \\
\text { part 2, p. 235) }\end{array}$ & & $\begin{array}{l}\text { /ko:m-ə-lhanafl } \\
\text { كوم الحنش (Unknown origin) } \\
\text { /hanas/ means "snake" } \\
\text { "serpent" in EA. }\end{array}$ \\
\hline
\end{tabular}

Masc. sing nouns are scarcely used with this schemain the data under analysis (3 out of 10$)$.

\subsubsection{Schemas which include $/ \operatorname{na} 3(\mathrm{~g}) \mathrm{S} /$ :}

The following table encompasses place names that are introduced by the word /nazS/ (Upper Egyptian pronunciation) or /nag S/ (variant). This word may be derived from the Arabic word (nuzGah) نجعة (the pursuit of grass and rainwater) (baheth). Masc. sing proper nouns constitute (6 out of 10). They can be represented by the following schema:

[naz(g)S [X]N.] Genitive Construction $\leftrightarrow$ The village of [X]

\begin{tabular}{|c|c|c|}
\hline \multicolumn{3}{|c|}{ Table (10) } \\
\hline $\begin{array}{c}\text { Original Forms } \\
\text { represented by } \\
\text { Ramzy and page } \\
\text { numbers }\end{array}$ & $\begin{array}{c}\text { Morpho-phonological } \\
\text { Changes }\end{array}$ & EA Pronunciation \\
\hline $\begin{array}{l}\text { /nazS نجع } \\
\text { Gisa:wiyyah/ } \\
\text { العيساوية (sec. 2, part } \\
\text { 4, p. 31) }\end{array}$ & $\begin{array}{l}\text { /nazS-əl-Yisaweyyah/ العيسوية } \\
\text { The /a:/ is shortened and } \\
\text { the first and second } \\
\text { occurrences of /i/ are } \\
\text { replaced by an /e/. }\end{array}$ & $\begin{array}{l}\text { /naz(g)S-əl- } \\
\text { Cesaweyyah/ العيسوية (probably from } \\
\text { the masc. proper nuon } \\
\text { of Eisa) }\end{array}$ \\
\hline $\begin{array}{l}\text { /naz̧ ma:zin yārb/ } \\
\text { نجع مازن غرب (sec. } \\
\text { 2, part 4, p. 106) }\end{array}$ & $\begin{array}{l}\text { 1- The word /yārb/ } \\
\text { meaning "west" is } \\
\text { deleted. } \\
\text { 2- The /i/ of ma:zin is } \\
\text { replaced by an /e/ in EA. }\end{array}$ & $\begin{array}{l}\text { /naz(g)S ma:zen/ مازن (Unknown origin) } \\
\text { masc. proper noun }\end{array}$ \\
\hline
\end{tabular}




\begin{tabular}{|c|c|c|}
\hline $\begin{array}{l}\text { /naz̧ Pal-fā?r/ نجع الفار (sec. 2, part 4, } \\
\text { p. 133) }\end{array}$ & $\begin{array}{l}1-\text { The } / R / \text { in both the } \\
\text { definite article and the } \\
\text { noun is dropped and the } \\
/ \overline{\mathrm{a}} / \text { is lengthened in EAto } \\
\text { compensate for the loss } \\
\text { of } / 2 / . \\
2-\mathrm{A} / \curvearrowright / \text { is inserted for } \\
\text { juncture. }\end{array}$ & $\begin{array}{l}\text { /naz/gS-ə-lfā:r/ نجع الفار } \\
\text { Masc. proper noun } \\
\text { (Unknown origin) }\end{array}$ \\
\hline 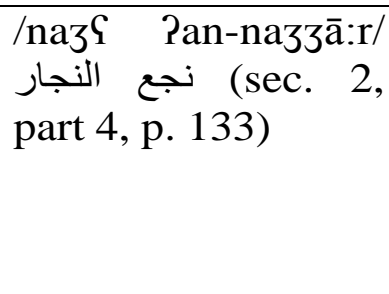 & $\begin{array}{l}\text { A } / \partial / \text { is added for } \\
\text { juncture. }\end{array}$ & $\begin{array}{l}\text { /naz(g)S-ə- } \\
\text { nnaz3(gg)ā:r/ نجع النجار meaning } \\
\text { النجار } \\
\text { carpenter- a masc. } \\
\text { sing noun (unknown } \\
\text { origin) }\end{array}$ \\
\hline $\begin{array}{l}\text { /nazS tamma:m/ نجع (sec. 2, part 4, } \\
\text { نمام 134) } \\
\text { p. 134) }\end{array}$ & $\begin{array}{l}\text { A } / \partial / \text { is added for } \\
\text { juncture. }\end{array}$ & 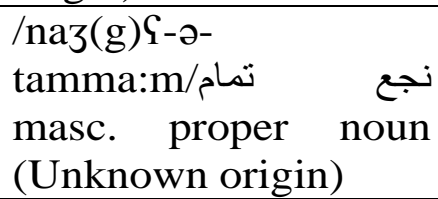 \\
\hline $\begin{array}{l}\text { /nazS țā:?iS/ نجع طايع } \\
\text { (sec. 2, part 4, p. } \\
\text { 134) }\end{array}$ & $\begin{array}{l}\text { 1- A /O/ is added for } \\
\text { juncture and the final /i/ } \\
\text { is replaced by an /e/. } \\
\text { 2- The /y/ was originally } \\
\text { /P/ in SA, a phenomenon } \\
\text { known as Pibda:1 Pal- } \\
\text { hamza البدال الهمزة (Hilal, } \\
\text { 1993, p.rr). }\end{array}$ & 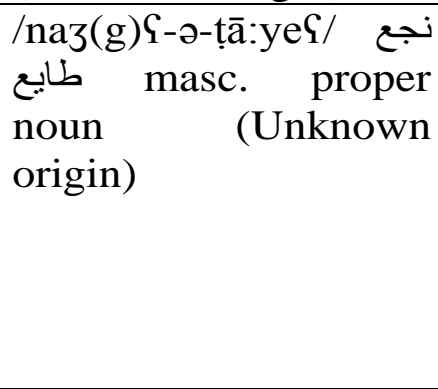 \\
\hline $\begin{array}{l}\text { /nazS hamad/ نجع } \\
\text { حمد (sec. 2, part 4, } \\
\text { p. 148) }\end{array}$ & $\begin{array}{l}\text { A } / \mathrm{a} / \text { is added for } \\
\text { juncture. }\end{array}$ & $\begin{array}{l}\text { /naz }(\mathrm{g}) \mathrm{S}-\mathrm{-}-\mathrm{hamad} / \mathrm{Q} \\
\text { حمد masc. proper noun } \\
\text { (Unknown origin) }\end{array}$ \\
\hline 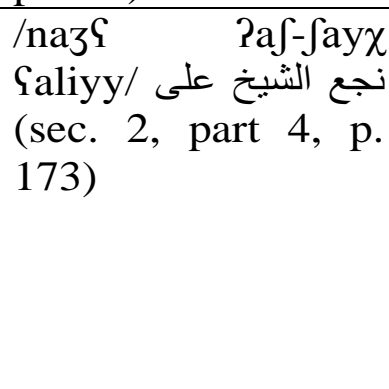 & $\begin{array}{l}\text { 1- The definite article is } \\
\text { assimilated into / } / \text { and a } \\
\text { /a/ is inserted instead of } \\
\text { the /a/. } \\
\text { 2- The /ay/ is replaced by } \\
\text { /ee/. } \\
\text { 3- The /yy/ ending is } \\
\text { elided. }\end{array}$ & 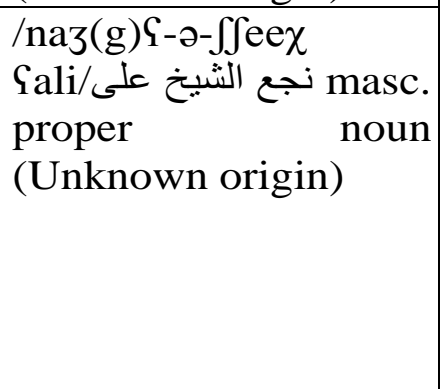 \\
\hline 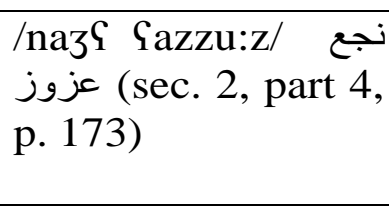 & $\begin{array}{l}\text { A } / \mathrm{a} / \text { is added for } \\
\text { juncture. }\end{array}$ & 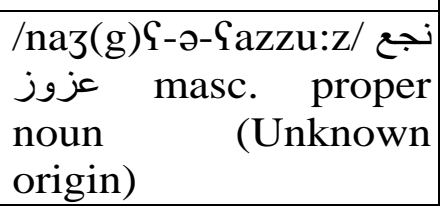 \\
\hline $\begin{array}{l}\text { /nazf hamma:di/ } \\
\text { حمادى (sec. 2, } \\
\text { part 4, p. 208) }\end{array}$ & $\begin{array}{l}\text { A } / \mathrm{a} / \text { is added for } \\
\text { juncture. }\end{array}$ & $\begin{array}{c}\text { /naz(g)-ə- } \\
\text { hamma:di/ نجع(masc. singular nd } ح م ا د ى(m)\end{array}$ \\
\hline
\end{tabular}

\subsubsection{Eponymy and Derivation: Schemas with Nisba Suffix:}

The following table introduces place names that are derived from the names of famous characters either in these places in particular or in Egypt in general. To form these place names, the feminine nisba suffix (iyyah) is 
attached to the original proper noun. In EA, this suffix is pronounced as /eyyah/. According to Ryding (2005), one way to generate nouns in Arabic is "through suffixing the feminine nisba ending -eyya (ية) to an already existing word stem". This process is essential to form new concepts in MSA (p. 90). These place names have carried their names, since they were founded. The word formation process that is deployed here is derivation by affixation.

The place names in this table can be represented by the following schema:

[?el [X]proper noun+suffix(eyyah)]

\begin{tabular}{|c|c|c|}
\hline \multicolumn{3}{|c|}{ Table (11) } \\
\hline $\begin{array}{c}\text { Original Forms } \\
\text { represented by } \\
\text { Ramzy and page } \\
\text { numbers }\end{array}$ & $\begin{array}{l}\text { Morpho-phonological } \\
\text { Changes and EA } \\
\text { Pronunciation }\end{array}$ & The reason behind naming \\
\hline $\begin{array}{l}\text { /RaTH-THā:hiriyyah/ } \\
\text { الظاهرية (sec. 2, part 1, } \\
\text { p. 68) }\end{array}$ & $\begin{array}{l}\text { /Pedi-dāhreyyah/ } \\
\text { /الضان (4 syllables) } \\
\text { 1- The /TH/ is replaced } \\
\text { by /ḍ/ in EA, which is } \\
\text { similarly a voiced } \\
\text { emphatic; yet post-dental, } \\
\text { since interdentals are } \\
\text { difficult to pronounce } \\
\text { in EA (for ease of } \\
\text { articulation). } \\
\text { 2- The vowel /ā:/ is } \\
\text { shortened. } \\
\text { 3- The /i/ is elided. }\end{array}$ & $\begin{array}{l}\text { It is named so after its founder, Al- } \\
\text { Thaher Beibars Al-Bindiqdaariy }\end{array}$ \\
\hline $\begin{array}{l}\text { /Ral-Sazi:ziyyah/ } \\
\text { العزيزية (sec. 2, part 2, } \\
\text { p. 70) }\end{array}$ & $\begin{array}{l}\text { /العززية/2el-Sazizeyyah } \\
\text { (5 syllables) } \\
\text { 1- The long vowel /i:/ } \\
\text { is shortened in EA /i/. } \\
\text { 2- The /i/ is replaced by } \\
\text { /e/ in EA. }\end{array}$ & $\begin{array}{l}\text { It is named after PalSaziiz bi-llah } \\
\text { Nizā:r Ibn Al-MoYizz li-di:ni- } \\
\text { llahAlFā:țimiyy }\end{array}$ \\
\hline $\begin{array}{l}\text { /Pal-husayniyyah/ } \\
\text { (sec. 2, part 1, } \\
\text { p. 119) }\end{array}$ & $\begin{array}{l}\text { /Rel-hisineyyah/ الحسنيه } \\
\text { (5 syllables) } \\
\text { 1- Both The /u/ sound, } \\
\text { and the /ay/ are } \\
\text { replaced by an /i/. } \\
\text { 2- The /i/ of the suffix } \\
\text { is replaced by an /e/ in } \\
\text { EA. }\end{array}$ & $\begin{array}{l}\text { After Sheikh Hussein Ahmed Al- } \\
\text { Wanisi, the owner of one of the } \\
\text { Territories there. }\end{array}$ \\
\hline $\begin{array}{l}\text { /Pal-Qā:simiyyah/ } \\
\text { (sec. 2, part 3, p. 89) }\end{array}$ & $\begin{array}{l}\text { /Pel- } \\
\text { P(g)asmeyyah/ الأسمية أو (4 syllables) } \\
\text { الجسمية } \\
1-\text { The SA /q/ /q/ is } \\
\text { either retatined } \\
\text { (Rashi:d dialect), or } \\
\text { replaced by an / / or /g/ } \\
\text { in EA. } \\
2-\quad / \bar{a}: / \quad \text { sound is }\end{array}$ & $\begin{array}{l}\text { After Qa:sim Mohamed Aya } \\
\text { MarGashli, the owner of one of the } \\
\text { territories there. }\end{array}$ \\
\hline
\end{tabular}




\begin{tabular}{|c|c|c|}
\hline & $\begin{array}{l}\text { shortened and the } / \mathrm{i} / \mathrm{is} \\
\text { dropped. }\end{array}$ & \\
\hline $\begin{array}{l}\text { /Pal-hig(3)a:ziyyah/ } \\
\text { الحجازية } \\
\text { (sec. 2, part 1, p. 119) }\end{array}$ & $\begin{array}{l}\text { /Pel-hig(3)azeyyah/ } \\
\text { الحِجَزية (5 syllables) } \\
\text { 1- EA /g/ replaced /3/ } \\
\text { or was originally used } \\
\text { as a variant. } \\
\begin{array}{l}\text { 2-Vowel la:/ is } \\
\text { shortened. }\end{array}\end{array}$ & $\begin{array}{l}\text { This name is derived from the name } \\
\text { of Šeikh Metwalli Somar hegaazy, } \\
\text { one of the landowners in this area. }\end{array}$ \\
\hline $\begin{array}{l}\text { Pas-sā:lihiyyah/ } \\
\text { الصنالحية (sec. 2, part 1, } \\
\text { p. 112) }\end{array}$ & $\begin{array}{l}\text { /Pes-sālheyyah/الصلحية } \\
\text { (4 syllables) } \\
\text { 1-The /ā:/ is shortened } \\
\text { and the /i/ is dropped. } \\
\text { 2- The /i/ is replaced by } \\
\text { /e/. }\end{array}$ & $\begin{array}{l}\text { It was founded by king Passā:leh } \\
\text { Najmu-d-diin Ayyoub and was } \\
\text { called after him. }\end{array}$ \\
\hline $\begin{array}{l}\text { /PaTH- } \\
\text { THāwā:hiriyyah/ } \\
\text { الظواهرية (sec. 2, part } \\
\text { 1, p. 121) }\end{array}$ & $\begin{array}{l}\text { /Pedụāwāhreyyah/ } \\
\text { syllables) الضوهرية/5 } \\
\text { 1-The /TH/is replaced } \\
\text { by a /d̂ in EA, which is } \\
\text { similarlyvoiced } \\
\text { emphatic; yet post- } \\
\text { dental,since interdentals } \\
\text { are difficult to } \\
\text { pronounce in EA. } \\
\text { 2-the /ā:/ is shortened } \\
\text { and the /i/ is dropped. } \\
\text { 3-the /i/ changes into } \\
\text { /e/. }\end{array}$ & $\begin{array}{l}\text { After Sheikh Ibrahim Mousa Al- } \\
\text { ZZāwahri, the first mayor to be } \\
\text { assigned there. }\end{array}$ \\
\hline $\begin{array}{l}\text { /Pal-Pisma:Cilliyyah/ } \\
\text { الإسماعيلية(sec. 2, part } \\
\text { 2, p. 80) }\end{array}$ & $\begin{array}{l}\text { /Rel-esmaSil(1)eyyah/ (6 } \\
\text { syllables) } \\
\text { 1- The /?/ is elided. } \\
\text { 2- The /i/ changes into } \\
\text { /e/. } \\
\text { 3- The /a:/ is shortened } \\
\text { to /a/. } \\
\text { 4- The /1/ is at times } \\
\text { degeminated. } \\
\text { 5-the /i/ changes into } \\
\text { /e/. }\end{array}$ & After $\chi$ edeewi Ismail \\
\hline $\begin{array}{l}\text { /Pās-sābriyyah/ } \\
\text { الصبريناة(sec. 2, part 2, } \\
\text { p. 80) }\end{array}$ & $\begin{array}{l}\text { /Pes-sābreyyah/ } \\
\text { syllables). } \\
\text { The /i/ changes into } \\
\text { /e/. }\end{array}$ & $\begin{array}{l}\text { After its founder Hassan Sabri Pasha, } \\
\text { one of Egypt's ex-prime ministers. }\end{array}$ \\
\hline 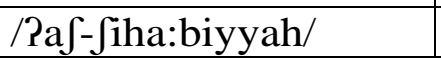 & 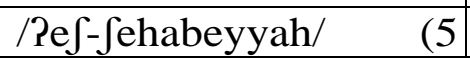 & Origin unknown (probably after the \\
\hline
\end{tabular}




\begin{tabular}{|c|c|c|}
\hline $\begin{array}{l}\text { (الثهابية (sec. 2, part 2, } \\
\text { p. 41) }\end{array}$ & $\begin{array}{l}\text { syllables) الثهبية } \\
1-\text { The /a/ and /i/are } \\
\text { replaced by an /e/. } \\
\text { 2-The /a:/ is shortened } \\
\text { to /a/ EA. }\end{array}$ & mas sing proper noun $\int \mathrm{iha}$ b) \\
\hline $\begin{array}{l}\text { /Pal-GuOma:niyyah/ } \\
\text { العثمانية (sec. 2, part 2, } \\
\text { p. 41) }\end{array}$ & $\begin{array}{l}\text { /Pel-Setmanneyyah/ (5 } \\
\text { syllables) العتمانية } \\
\text { 1- The /u/ is replaced } \\
\text { by an /e/. } \\
2-\text { The voiceless } \\
\text { interdental / } / \text { / is } \\
\text { replaced by a voiceless } \\
\text { dental/t/, for ease of } \\
\text { articulation. } \\
3 \text { - The /a:/ is shortened. } \\
4-\text { the /n/ is geminated } \\
\text { as compensatory to } \\
\text { vowel shortening. } \\
\text { (According to Watson } \\
\text { (2002), the length of one } \\
\text { segment is dependent on } \\
\text { other adjacent ones. } \\
\text { Hence, the shortening of } \\
\text { vowels may trigger } \\
\text { gemination } \\
\text { consonants). } \\
5-\text { The /i/ changes into } \\
\text { /e/. }\end{array}$ & $\begin{array}{l}\text { This place is called after Sheikh } \\
\text { Mohamed Othman, the owner of one } \\
\text { of the districts in this area. }\end{array}$ \\
\hline
\end{tabular}

It is to be noted that the names had regularly undergone changes, if they were founded as SA names, conversely, if they were created as colloquial ones, they usually remain without modificiation. All the above place names are derived from masculine proper nouns. They characteristically consist of 4-5 syllables, with only one with 6 syllables. Moreover, when there is a long vowel like /a:/ or /ā:/, it is usually shortened in EA. Such place names can be considered as cases of eponymy in Arabic; since they are all derived from proper masc. names of people or groups.

\subsubsection{Schemas formed through eponymy:}

The following table includes similar place names to the ones presented in the previous table. These places carry the same canonical pattern. They have also undergone similar changes. The long vowels /a:/ or /ā:/ are always shortened in the EA form. In addition, the $/ \mathrm{i} / \mathrm{in}$ the penultimate syllable is dropped and the definite article /Pal/ is replaced by / Pel/ (lunar) or / $\mathrm{ee}+\mathrm{CC} /$ (solar), according to the first letter of the base word. The EA forms of these names have undergone base modifications as there is not any new material added to the original forms, yet the change mainly affects the 
quality of the vocalic system of the original names that are all names of Arabic tribes that are used as they are. These words can be schematized as follows:

[?el-CaCa(a)CCah]plu. N. $\leftrightarrow$ after the name of a tribe $[$ ?e-CCaCa(a) $\mathrm{CCah}]$ plu. N. $\leftrightarrow$ after the name of a tribe

\begin{tabular}{|c|c|c|}
\hline \multicolumn{3}{|c|}{ Table (12) } \\
\hline $\begin{array}{c}\text { Original Forms } \\
\text { represented by } \\
\text { Ramzy and page } \\
\text { numbers } \\
\end{array}$ & $\begin{array}{c}\text { Morpho-phonological } \\
\text { Changes }\end{array}$ & Meaning \\
\hline $\begin{array}{l}\text { /Ras-salā:ținah/ } \\
\text { السلاطنة (sec. 2, part } \\
\text { 1, p. 120) }\end{array}$ & $\begin{array}{l}\text { /Pes-sālāțah/ السلطنة } \\
1 \text { - The /s/ is pronounced } \\
\text { as /s/ in currentEA, } \\
\text { consequently the /a/ } \\
\text { changed into /â/. } \\
\text { 2- The /ā:/ is shortened } \\
\text { and the /i/ is dropped. }\end{array}$ & $\begin{array}{l}\text { The tribe comes from a } \\
\text { man named Sultan. The } \\
\text { current form uses the } \\
\text { plural form of the masc. } \\
\text { proper name 'Sultan'. }\end{array}$ \\
\hline $\begin{array}{l}\text { /Pas-sama:Sinah/ } \\
\text { السماعنة (sec. 2, part } \\
\text { 1, p. 120) }\end{array}$ & $\begin{array}{l}\text { /Pes-samaYnah/السمعنه } \\
\text { The /a:/ is shortened and } \\
\text { /i/ is dropped in EA. }\end{array}$ & $\begin{array}{l}\text { /Pas-sama:Sinah/ are } \\
\text { Palestinian people (tribe) } \\
\text { who dwelled in this } \\
\text { territory and it was called } \\
\text { after them (from masc. } \\
\text { proper name SamSa:n). }\end{array}$ \\
\hline $\begin{array}{l}\text { /Pan-nawa:fiSah/ } \\
\text { النو افعة (sec. 2, part 1, } \\
\text { p. 122) }\end{array}$ & $\begin{array}{l}\text { /Pen-nawafSah/ النوفعه } \\
\text { The /a:/ is shortened and } \\
\text { the /i/ is dropped. }\end{array}$ & $\begin{array}{l}\text { The name of a tribe (from } \\
\text { masc. proper name } \\
\text { Na:fiS) }\end{array}$ \\
\hline $\begin{array}{l}\text { /Pan-naSa:minah/ } \\
\text { النعامنة (sec. 2, part 1, } \\
\text { p. 140) }\end{array}$ & $\begin{array}{l}\text { /Pen-naSamnah/النعمنة } \\
\text { The /a:/ is shortened and } \\
\text { the /i/ is dropped. }\end{array}$ & $\begin{array}{l}\text { The name of a tribe (from } \\
\text { masc. proper name } \\
\text { NuYma:n) }\end{array}$ \\
\hline $\begin{array}{l}\text { /Ral-Sala:qimah/ } \\
\text { العلاقمة (sec. 2, part 1, } \\
\text { p. 155) }\end{array}$ & $\begin{array}{l}\text { /Pel-SalaP(g)mah/ العَلَئمة } \\
\text { 1- The /q/ is replaced by } \\
\text { an /R/ or /g/in EA. } \\
\text { 2- The /a:/ is shortened } \\
\text { and the /i/ is dropped. }\end{array}$ & $\begin{array}{l}\text { This is the name of an } \\
\text { Arabic tribe }\end{array}$ \\
\hline $\begin{array}{l}\text { /Pas-saka:kirāh/ } \\
\text { السكاكرة(sec. 2, part 2, } \\
\text { p. 161) }\end{array}$ & 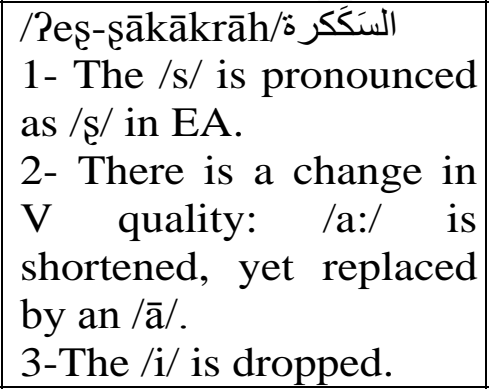 & $\begin{array}{l}\text { The name of an Arabic } \\
\text { tribe }\end{array}$ \\
\hline $\begin{array}{l}\text { /Ras-sata:yitah/ الستايتة } \\
\text { (sec. 2, part 1, p. } \\
\text { 206) }\end{array}$ & $\begin{array}{l}\text { /Pes-sataytah/ الستَايتة } \\
\text { 1-The /a:/ is shortened } \\
\text { and the /i/ is dropped. }\end{array}$ & Unknown origin \\
\hline 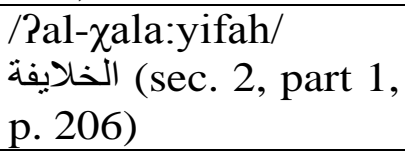 & 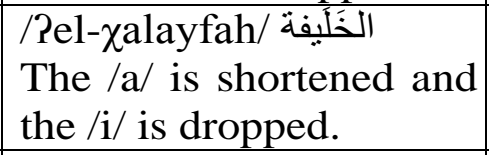 & $\begin{array}{l}\text { The name of an Arabic } \\
\text { tribe }\end{array}$ \\
\hline /Pal-ৎasāafirāh/ & العصفرة /Rel-Yāşāfrāh & The name of an Arab \\
\hline
\end{tabular}




\begin{tabular}{|c|c|c|}
\hline $\begin{array}{l}\text { (sec. 2, part } \\
\text { 1, p. 207) }\end{array}$ & $\begin{array}{l}\text { 1-The /a/ changes into } \\
/ \bar{a} / \text { under influence from } \\
\text { its envirnment. } \\
\text { 2- The } / \overline{\mathrm{a}} \text { :/ is shortened } \\
\text { and the } / \mathrm{i} / \text { is dropped. }\end{array}$ & tribe \\
\hline $\begin{array}{l}\text { /Pal-SaOa:minah/ } \\
\text { العثامنة (sec. 2, part 4, } \\
\text { p. 81) }\end{array}$ & $\begin{array}{l}\text { /Rel-Gatamnah/ العنامنة } \\
\text { The / } \theta / \text { is replaced by a } \\
\text { /t/, for ease of } \\
\text { articulation, the /a:/ is } \\
\text { shortened and the /i/ is } \\
\text { elided. }\end{array}$ & $\begin{array}{l}\text { The name of an Arabic } \\
\text { tribe (from the masc. } \\
\text { proper name }\{u \theta \text { ma:n) }\end{array}$ \\
\hline
\end{tabular}

All the place names in the above table consist of 4-5 syllables. These words too are composed by means of eponymy as they are derived from the names of Egyptian tribes. Moreover, another significant remark is that the shortening of vowels in these words reflects economy of speech. Dansei (2004) refers to Zipf's (1949) law of economy or "the Principle of Least effort". The principle proposes "that the ways in which human beings organize their linguistic systems and exert themselves in speaking tend towards least effort". Zipf (1949) has discovered that the more repeatedly a word is used, "the more it tended to be "shorter" (made up with fewer phonemes)" (as cited in Dansei, 2004, p.12). This phenomenon is observed in several instances throughout the corpus.

\subsubsection{Sociopragmatic change: Euphemistic Schemas:}

The place names in the following table have undergone complete changes in order to meet their inhabitants' social needs. In other words, some Egyptian place names used to have bad or offensive names. Consequently, the inhabitants of such places found it necessary to change such names into more appropriate ones. Hence, it is a sociopragmatic change. The term 'sociopragmatics' was coined by Leech (1983, p. 10). It tackles the "social interface of pragmatics" i.e. "the social rules that constrain and govern speakers' linguistic choices and hearers' possible interpretation" (Timpe, 2012, p. 111).

In the following set of names, the original forms were completely substituted by other new ones. In almost all cases, the new forms share an aspect of the original one. This aspect is sometimes a part or a syllable from the original form. At other times, the new form may contain some letters from the original one. It is significant to note that the derived place names have made use of the same word formation processes used in the previous tables. The words in the following table can be schematized as follows:

\section{[[X] Offensive Expression] $\leftrightarrow$ [[Y] Appropriate Expression]}

It is worth noting that the schema of each place name is provided with the new euphemistic form.

\begin{tabular}{|c|c|c|}
\hline \multicolumn{3}{|c|}{ Table (13) } \\
\hline $\begin{array}{c}\text { The Original Form } \\
\text { represented by Ramzy } \\
\text { and page numbers. }\end{array}$ & $\begin{array}{c}\text { Morpho-phonological } \\
\text { Changes }\end{array}$ & $\begin{array}{c}\text { EA Form and the word- } \\
\text { formation process + schema }\end{array}$ \\
\hline
\end{tabular}




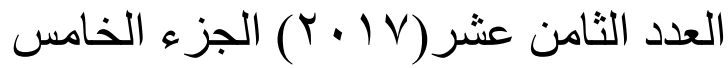

\begin{tabular}{|c|c|c|}
\hline $\begin{array}{l}\text { /Pal-mahru:qāh/ } \\
\text { المحروقة (The burned) } \\
\text { (sec. 2, part 1, p. 98) }\end{array}$ & $\begin{array}{l}\text { /Ralmahru:qāh > /Pis- } \\
\text { siYi:deyyah/ }\end{array}$ & $\begin{array}{c}\text { /Res-siGideyyah/ السعيدية } \\
\text { (Eponymy+derivation) } \\
\text { [?el [X]proper } \\
\text { noun+suffix(eyyah)] }\end{array}$ \\
\hline $\begin{array}{l}\text { /minyat hami:r/ } \\
\text { منية حمير } \\
\text { (the city of donkeys) } \\
\text { (sec. 2, part 1, p. 99) }\end{array}$ & $\begin{array}{l}\text { /menyat hami:r/ > /mi:t } \\
\text { hִemi:r/> } \\
\text { fa:ru:qeyyah/> } \\
\text { /Relfarug(P)eyyah/ }\end{array}$ & $\begin{array}{l}\text { /Pel-faruP(g)eyyah/ } \\
\text { الفاروقية } \\
\text { This place is named after king } \\
\text { Farouk I.(Eponymy+derivation) } \\
\text { [?el [X]proper } \\
\text { noun+suffix(eyyah)] }\end{array}$ \\
\hline $\begin{array}{l}\text { /g(3)azi:rat Pal-Gu:r/ العورة } \\
\text { The Island of the one- } \\
\text { eyed people (sec. 2, part } \\
\text { 3, p. 134) }\end{array}$ & $\begin{array}{l}\text { /g(3)azi:rat Pal-Gu:r/ } \\
\text { >/g(3)izi:ret-ə-nnu:r/ } \\
\text { The word } g(3) \text { azi:rat lost } \\
\text { the initial /a/ > /i/ and the } \\
\text { final /a/ > /e/ in EA. }\end{array}$ & $\begin{array}{l}\text { /g(3)izert-ə-nnu:r/ } \\
\text { جزيرة النور } \\
\text { The island of light } \\
\text { (compounding withgizi:ret) } \\
\text { [[g(3)izi:ret [X]N] }\end{array}$ \\
\hline 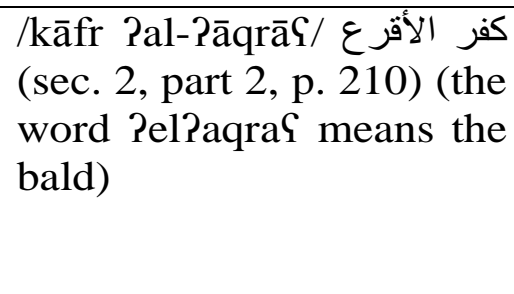 & 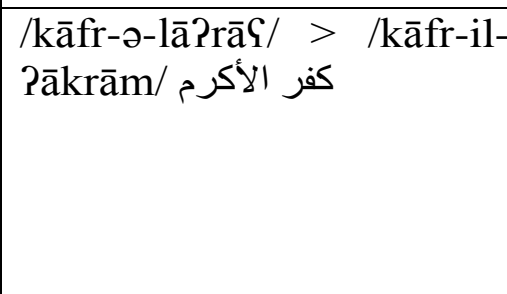 & $\begin{array}{l}\text { /kāfr- əl-Pākrām/ كفر الأكرم (the } \\
\text { word Pel-Pākrām means the } \\
\text { most generous). (compounding } \\
\text { with kāfr) } \\
\text { [kāfr [X]N] } \leftrightarrow \text { the village of } \\
\mathbf{X} \text {. }\end{array}$ \\
\hline $\begin{array}{l}\text { /bani mag(3)nu:n/ منىى (sec. 2, part 3, p. 98) } \\
\text { (the word magnu:n means } \\
\text { crazy) }\end{array}$ & $\begin{array}{l}\text { /bani magnu:n/ > /bani } \\
\text { sā:leḥ/ }\end{array}$ & 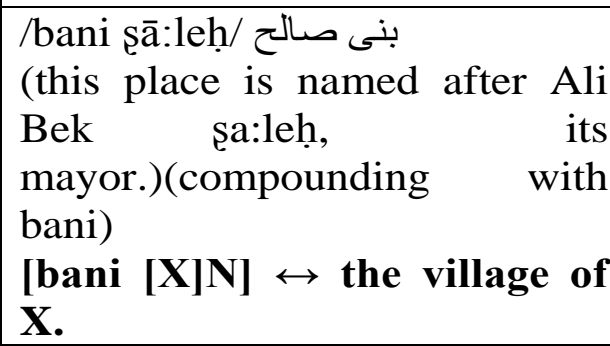 \\
\hline $\begin{array}{l}\text { /bani kalb/ بنى (sec. 2, part } \\
\text { 4, p. } 77 \\
\text { كلب (the word kalb means } \\
\text { dog) }\end{array}$ & $\begin{array}{l}/ \text { bani kalb/ > /bani } \\
\operatorname{mag}(3) \mathrm{d} /\end{array}$ & $\begin{array}{l}\text { /bani mag(3)d/ بنى مجد (the word } \\
\text { magd means glamor in Arabic) } \\
\text { and this place is named after a } \\
\text { famous Arabic tribe. } \\
\text { (compounding with bani) } \\
{[\text { bani }[\mathbf{X}] \mathbf{N}] \leftrightarrow \text { the village ofX. }}\end{array}$ \\
\hline
\end{tabular}

As mentioned earlier, the new forms of the place names presented above are created by the same techniques used in other Egyptian place names. For example, some of the above names are introduced by words like bani and kâfr. Others end in the feminine nisba - eyyah, with a predominance of compounding. Moreover, the word gazi:rah (island) is used to form many Egyptian place names. Half of the above data are Masc. proper names (3 out of $6)$.

\section{Results and Findings:}

Inspite of their different origins, Egyptian place names show a systematic number of properties ranging from the phonological, morphological, to the semantic and pragmatic ones. One significant point that should be emphasized 
is that the word formation schemas developed by Booij in his theory of Construction Morphology (2005) deal with English and Dutch. Both languages follow morphological systems that sometimes contradict with Arabic in many aspects, because both English and Dutch are concatenative languages, whereas Arabic is a non-concatenative one. Furthermore, Arabic has a different word order, and the order of combination is different. Since schemas are language specific, it was essential for the researcher to develop new schemas that represent the EA place names under analysis.

On the one hand, the framework of $\boldsymbol{C M}$ is considered an adequate tool to analyze Egyptian place names that were created after the Arabic conquest of Egypt. It could account for varied linguistic features i.e. semantic, syntactic, morphological, phonological and pragmatic. As shown above, these names have systematic properties that facilitate forming schemas to represent them. However, the archaic schemas of the place names of Ancient Egyptian and Coptic origins were difficult to generalize. In order to deal with these forms more accurately, it was necessary to consult different sources other than the Geographic Dictionary. Nevertheless, the place names of Ancient Egyptian and Coptic origin showed a number of systematic morpho-phonological changes between the original forms and the Arabic derived ones, yet no specific pattern is detected. These changes are as follows:

a) The /t/ changes either into a $/ \mathrm{d} /, / \mathrm{t} / \mathrm{or} / \mathrm{n} /$.

b) $\quad$ The $/ \mathrm{p} /$ changes into a $/ \mathrm{b} /$.

c) The $/ \mathrm{p} /$ or $/ \mathrm{b} /$ changes into a /f/.

d) Many consonants of the base words are elided.

e) There are many vowel changes.

As for names of Arabic origin, the researcher detected different features. A significant feature of one type of Egyptian place names is found in those forms that used to encompass the word /minyah (t)/ (pronounced as /menyet/ in EA when followed by another word). This word has been replaced by the word /mi:t/ meaning road. Although the origin of the word minyah is the Coptic word timoni (according to Ramzy), it was replaced by an Ancient Egyptian word i.e. mi:t. However, very few Egyptian place names still carry the word /minyah/. Minyal-q(?)āmh (منيا القمح) serves as one such instance. Similarly, the meanings of the analyzed data comprised many words (such as kāfr, Sezbah, nazlah, nagא, bani and ko:m) that carry controversial meanings. Thus, the researcher consulted varied sources and websites in order to reach the exact meanings of the data discussed. Sometimes, more than one meaning was given to one form and at other times, the meanings were left obscure, as it was difficult to reveal them.

A large number of Egyptian place names are phrasal compounds making use primarily of genitive constructions that start with fixed words like kāfr, nazlah, Gizbah, bani, Pabu, ko:m or nagG, and these words refer to villages, or locales. Such words introduce place names all over Egypt with the exception of the word naz $(\mathrm{g}) \mathrm{S}$ that is only used to form upper Egyptian place names. Thus, it was only found in part 4 of section two of Ramzy's dictionary (1994) which encompasses the upper Egyptian governorates. 
In the framework of Construction Morphology, such forms are identified as constructional idioms .i.e. morphological schemas with a fixed slot. These form most of the data under study, since about 83 percent of the corpus were formed using such idioms. In addition, from the sociopragmatic aspect, many places used to carry bad or offensive names. Consequently, their inhabitants found it necessary to change these names into more appropriate or euphemistic ones. To form such names, the Egyptians made use of the same techniques used to form place names like the genitive constructions.

Eponymy is also made use of in forming a number of Egyptian places (17 percent). In other words, some place names are derived from the names of famous characters in Egypt. Such names are either masc. proper nouns followed by the feminine nisba suffix - eyyah or plural nouns carrying the pattern Pel-CaCa(a) $\mathrm{CC}$ ah. Moreover, another significant remark concerning these names is that many of them displayed vowel shortening, change from interdentals to dental or alveolar sounds, velarization and dropping of phonemes. This was predictably governed, for the most part, by economy of speech, otherwise known as Zipf's (1949) law of economy or "the Principle of Least effort". This phenomenon was observed in several instances throughout the corpus. Moreover, unlike SA, EA proves to allow initial consonant clusters as in /sli:m/ and /mhammad/.

Several crucial points should be mentioned here. One of which is the interplay of Word Formation processes, observed in some paradigms, e.g. eponymy and derivation. Another critical observation is that most of the Egyptian place names carry masculine personal nouns with a percentage of about 60 percent of the data provided. This may reveal the Egyptian community as a macho culture or male dominant community, since no feminine names were detected in the data, probably for cultural or religious issues. It is noteworthy that usually a woman's name is not used in the countryside in certain Egyptian groups, as they regard it inappropriate to call her first name, preferring to use her father or her son's name. However, due to the limited data presented here, further research is required to consolidate this observation.

To conclude, compounding is the most recurrent word formation process used to create Egyptian place names; since about 70 percent of the words presented here are compounds. This proves Bauer (2009) and Booij's (2013) statement about compounding as the most prolific word formation process in relation to Arabic compounds too. Base modification comes after compounding, for 13 percent of the data provided are derived via base modification, then comes derivation with a 10 percent of the data derived by affixation. Some of them can be considered as cases of eponymy at the same time. The rest of the data makes use of all these word-formation processes to get euphemistic or appropriate place names from an unaccepted or offensive one.

\section{Recommendations for further research:}

Further research is needed to deal with EA words of Ancient Egyptian and Coptic origin. Moreover, studies should be devoted to address the 
semantics of the Egyptian place names; since it has been hard for the researcher to identify the meanings of many place names. Furthermore, nonconcatenative morphology should be studied within the framework of Construction Morphology to explore other lexical domains. Additionally, more linguistic studies should address aspects of the male dominant culture in Egypt. 


\section{References}

Ahmed, Brig (R) Zahoor. (2008). Essential of Arabic Grammar for Learning Quranic Language. Retrieved from https://asimiqbal2nd.files.wordpress.com/2009/06/arabicgrammar.pdf

Al-Jarf, Reima. (2011). Teaching English Word-Formation Processes to Translation Students. Komunkacija i Kultura Online, II, 160-174.

Al-Musa, Nihad. (1405 AH.). The Book of Naht in the Arabic Language. Riyadh.: Darul-Gulu:m.

Aronoff, Mark \&Fudemann, Kirsten. (2005).What is Morphology? Malden (MA): Blackwell Publishing.

Baheth search engine. Retrieved fromhttp://www.baheth.info/all.jsp?term=\%D9\%86\%D8\%B2\%D9\% $\underline{84 \% \mathrm{D} 8 \% \mathrm{~A} 9}$

Barðdal, Johanna. (2001). Case in Icelandic: A Synchronic, Diachronic and Comparative Approach. Lund: Dept. of Scandinavian languages, Lund University.

Beeman, William O. (1986). Language, Status, and Power in Iran. Bloomington: Indiana University Press.

Bishai, Wilson B. (1961). Nature and Extent of Coptic Phonological influence on Egyptian Arabic. Journal of Semitic Studies, 6, 175-182.

Booij, Geert, Lehmann, Christianv \& Mugdan, Joachim. (Eds.). (2000). (Traditional Arabic Grammar). In Morphologie: ein internationals Handbuch zur Flexion und Wortbildung:an international handbook on inflection and word-formation (pp. 67-76). Berlin: De Gruyter.

Booij, Geert. (2005). The Grammar of Words: An Introduction to Linguistic Morphology. New York, Ny: Oxford University Press.

Booij, Geert. (2009a). Compound Construction; Schemas or Analogy? A Construction Morphology Perspective.Cross Disciplinary Issues in Compounding Current Issues in Linguistic Theory, 93-108.

Booij, Geert. (2009b). Phrasal names: A constructionist analysis. Retrieved from

https://www.researchgate.net/publication/228974300_Phrasal_names _A_constructionist_analysis_1

Booij, Geert. (2010a). Construction Morphology.Language and Linguistics Compass 3/1, 1-13.

Booij, Geert (2010b). Morphological Analysis. In Bernd Heine \& Heiko Narrog (Eds.). The Oxford Handbook of Grammatical Analysis. Oxford: Oxford University Press.

Booij, Geert. (2012). Inheritance and Construction Morphology.Retrieved from https://geertbooij.files.wordpress.com/2014/02/booij-2015inheritance-issues-in-construction-morphology-feb-2014.pdf

Booij, Geert. (2013). Morphology in Construction Grammar. The Oxford Handbook of Construction

Grammar.ThomasHoffmannandGraemeTrousdale(Eds.).Oxford:OxfordUnive rsityPress.Retrieved fromhttps://geertbooij.files.wordpress.com/2014/02/booij-2013morphology-in-cxg.pdf 
Broccias, Cristiano. (2006). Cognitive Approaches to Grammar. In Kristinsen, G. Cognitive Linguistics: current applications and future perspectives (pp. 81-115). Berlin: Mouton de Gruyter.

Bucholtz, M., \& Hall, K. (2008).All of the Above: New Coalitions in Sociocultural Linguistics. Journal of Sociolinguistics, 12(4), 401-431.

Bueasa, Noor M. (2015). The Adaptation of Loanwords in Classical Arabic: The Governing Factors (MA dissertation). University of Kentucky, USA.

Bybee, Joan. (2010). Language Usage and Cognition. Cambridge: Cambridge University Press.

Danesi, Marcel. (2004). A Basic Course in Anthropological Linguistics. Toronto, Ontario: Canadian Scholars' Press Inc.

Danesi, Marcel. (2015). Language, Society and New Media: Sociolinguistics Today. New York, NY: Routledge.

El-baz, Sarah. (2014). The origin of the word mi:t in the names of Egyptian villages. Retrieved from cairodar.youm7.com.

Elhadary, Osman. (2016). Moses in the Holy Scriptures of Judaism, Christianity and Islam: A Call for Peace. United States: Bookbaby.Retrieved from https://books.google.com.eg/books?id=4ReDQAAQBAJ\&pg=PT46\&lpg=PT46\&dq=mousa+means+son+of + water+in+egyptian\&source $=$ bl\&ots $=$ NU3E0R BEq\&sig $=8 \mathrm{bs}-$

G4qYkcscHzEPKN6CwmE1U4A\&hl=en\&sa=X\&ved=0ahUKEwjlu vmV18bRAhUDC8AKHSNACsYQ6AEIIjAB\#v=onepage $\& \mathrm{q}=$ mous a\%20means\%20son\%20of\%20water\%20in\%20egyptian\&f=false

El Zarka, Dina. Reduplication and Gemination in Arabic Verbal Morphology: One Phenomenon or Two Distinct Mechanisms? Retrieved fromhttps://www.researchgate.net/publication/251813339

El-Zawawy, Amr M. (2009).The Foundations of Construction Grammar.California Linguistic Notes.

Vol. XXXIV, 1.

Ferguson, C. A. (1959). Diglossia.Word, 15, 325-340.

Gadalla, A.H \& Abdel-Hamid, Abdel-Nasser, M.E. (2000). Genitive Constuctions in English and Arabic: A Contrastive Study. The Bulletin of the Faculty of Arts, Assiut University, Egypt. Vol. 6, 1-64.

Gadalla, Hassan A.H. (2000). Comparative Morphology of Standard and Egyptian Arabic. Muenchen: Lincom Europa.

Ghnim, Dr. Salaha Rashad. (1120 AH.) Al-Lahazat fi Al-kita:b Li Sebawayh Paswatan wa Bunyah . Cario: Maktabt Al- anglo Al-amrikiyyah.

Gigliogi, P. P. (Ed.). (1972). Language and Social Context: Selected Readings. England: Penguin Books.

Goldberg, Adele. (1995). Constructions: A Construction Grammar Approach to Argument Structure. Chicago: Chicago University Press.

Goldberg, Adele E. (2003). Constructions: A New Theoretical Approach to Language Trends in Cognitive Sciences. TRENDS in Cognitive Sciences, Vol. 7, 5, 219-224. 
Gomathi, B.S. (2014). A Study of Sociolinguistics With A Special Emphasize to Language Learning. The Dawn Journal. Vol. 3, 2, 981-989.

Gurevich, Olga I. (2006). Construction Morphology: The Georgian Version (Doctoral dissertation). University of Californai, Berkeley.

Haspelmath, Martin \& Sims, Andrea D. (2010).Understanding Morphology $\left(2^{\text {nd }}\right.$ ed). London: Hodder Education.

Hickey, Raymond. (Ed.). (2010). The Handbook of Contact Linguistics. Chichester, West Sussex: Wiley-Blackwell.

Hockett, Charles F. (1958). A Course in Modern Linguistics. New York: Macmillan Company.

Holmes, J. (1992). An Introduction to Sociolinguistics. London: Longman.

Izzo, Herbert J. (1975). Concerning the Influence of Native American Languages on American Spanish. ERIC, Retrieved from https://eric.ed.gov/?id=ED107148

Jabbari, Mohamed Jafar. (2012). Diglossia in Arabic A Comparative Study of the Modern Standard Arabic and Egyptian Colloquial Arabic. Global Journal of Human Social Science. Vol. 12, Issue 8, 23-36.

Jackendoff, Ray. (2002). Foundations of Language. Oxford: Oxford University Press.

Jackendoff, Ray. (2007). A Parallel Architecture Perspective on Language Processing.Brain Research, 1146, 2-22.

Kayfa Tufarriq bayn-al-taa' Al-Maftuuha wa-1-Marbuutah. Retrieved fromhttps://docs.google.com/document/d/1eeK4CjLFYcrWI4QNrjR 9wkb7bHKaW5gzC716_5GRIIM/preview

Khrisat, Abdulhafeth Ali \& Mohamad, Majiduddin Sayyed. (2014). Language's Borrowings: The Role of the Borrowed and Arabized Words in Enriching Arabic Language.American Journal of Humanities and Social Sciences. Vol. 1, 2, 133- 142.

Kramer, Ruth. (2007). Nonconcatenative Morphology in Coptic.Retrieved from http:// www. Bing.com

LaPolla, Randy J. (2009). Causes and Effects of Substratum, Superstratum and Adstratum Influence, with Reference to Tibeto-Burman Languages.Senri Ethnological Studies, 75, 227-237.

Leech. G.N. (1983). Principles of Pragmatics. London: Longman.

Loprieno, Antonio. (1995). Ancient Egyptian: A Linguistic Introduction. Cambridge: Cambridge University Press.

Loprieno, Antonio. (1997). Egyptian and Coptic Phonology. In Kaye, Alan, S. (Ed.), Phonologies of Asia and Africa: Including the Caucasus (pp. 431-460).Winona Lake, Indiana: Eisenbrauns.

Mangrio, Riaz Ahmed. (2016). The Morphology of Loanwords in Urdu: The Persian, Arabic and Englsih Strands. Cambridge: Cambridge Scholars' Publishing.Retrieved fromhttps://books.google.com.eg/books?id=cd_6DAAAQBAJ\&pg=P A58\&lpg=PA58\&dq=examples+of+base+modification+in+arabic\&s ource $=$ bl\&ots $=$ GKZc0_rdd6\&sig $=\_J 6 f D g z B X Q W u X p i J W 1 u J 1 z e C y c$ $E \& h l=e n \& s a=X \& v e d=0 a h U K E w j h z 9 b b k 8 b R A h X I K M A K H Q a U B j k$ Q6AEIQjAE\#v=onepage\&q=examples\%20of\%20base\%20modificat ion\%20in\%20arabic\&f $=$ false

Mello, Heliana. (2014). What Corpus Linguistics Can Offer Contact Linguistics: the C-Oral-Brasil Corpus Experience. PAPIA.407-427. 
Michaelis, Laura A. \&Lambrecht, Knud. (1996). Toward a Construction-based theory of Language Function: The Case of Nominal Extraposition. Language. 72, 215-247.

Mlinar, Romeo. (2010, May 22). Language - Synchrony and Diachrony (4/7).

Retrieved from

http://www.languagebits.com/historical-linguistics/language-synchrony-

diachrony/

Mohammed, Wi'am Majeed. (2015). Blending in Arabic and English. Journal of Babylon University for Humanities. Vol. 23(4), 1910-1922.

Nkamigbo, Linda Chinelo. (2012). A Socio-Morphological Analysis of Koring Verbal Greetings.AFRREV IJAH An International Journal of Arts and Humanities. Vol. 1(3), 104-115.

Oriabi, Hawraa Hasan. (2012). A Contrastive Study of Clipping in English and Arabic. 10, 1-26.

Paoletti, Isabella. (2011). Sociolinguistics. Sociopedia.isa. 10, 1-14.

Prihantora, D. (2009). English Loanwords in Korean. Retrieved from http:// linguistics-Prihantoro.blogspot.com/2009/04/English-loanwords-in Korean.html.

Ramzy, Mohamed. (1994). The Geographical Dictionary. (Vol. 2-6). Cairo: The Egyptian General Book Organization.

Ryding, Karin C. (2005). A Reference Grammar of Modern Standard Arabic. Cambridge: Cambridge University Press.

Sankoff, Gillian. (2001). Linguistic Outcomes of Language Contact.In Peter Trudgill, J. Chambers \& N. Schilling-Estes(eds.),Handbook of Sociolinguistics. Oxford: Basil Blackwell, pp. 638-668.

Sayahi, Lotfi. (2014). Diglossia and Language Contact: Language Variation and Change in North Africa. Cambridge, UK: Cambridge University Press.

Siemund, Peter. (n.d.).Language Contact: Constraints and Common Paths of Contact-induced Language Change.

Simpson, Andrew Kingsbury. (2009). The Origin and Development of Nonconcatenative Morphology (Doctoral dissertation).University of California, Berkely.

Thomason, Sarah G. (2001). Language Contact: An Introduction. Washington, D.C.: Georgetown University Press.

Timpe, Vernika. (2012). Strategic Decoding of Sociopragmatics Assessment Tasks-An Explanatory Think-Aloud Validation Study. Second Language Studies, 30(2), 109-246.

Trask, R.L. (1996). A Dictionary of Phonetics and Phonology. London: Routledge.

Trudgill, Peter (Ed.). (1984). Introduction. In Applied Sociolinguistics (pp. 14). London: Academic Press, INC.

Tsujimura, Natsuko \& Davis, Stuart.(2011). A Construction Approach to Innovative Verbs in Japanese.Cognitive Linguistics.799-825.

Wardhaugh, Ronald. (2006). An Introduction to Sociolinguistics. Oxford: Blackwell Publishing.

Watson, Janet C.E. (2002). The Phonology and Morphology of Arabic. Oxford: Oxford University Press. 
Winford, Donald. (2003). An Introduction to Contact Linguistics, Oxford: Wiley- Blackwell Publishing.

Yule, George. (1996). The Study of Language ( $2^{\text {nd }}$ ed). Cambridge: Cambridge University Press.

Zapata, Argenis A. (2007). Types of Words and Word-Formation Processes in English. Escuela de Idiomas Modernos, Universidad de Los Andes, 1-23. 